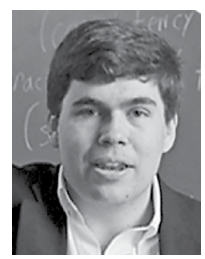

\author{
Christian B. Miller •
}

\title{
CZY LUDZIE SA W WIĘKSZOŚCI UCZCIWI, CZY NIEUCZCIWI? A MOŻE ANI TACY, ANI TACY?
}

\begin{abstract}
Stowa kluczowe
Streszczenie

charakter,

W swojej pracy skupiam się wyłącznie na jednej sferze uczciwość, moralności, a mianowicie na oszukiwaniu oraz motywacji nieuczciwość, do niego, i badam, czy istnieje empiryczne świadectwo na oszukiwanie, rzecz istnienia odpowiedniej cnoty - uczciwości i wady cnota, wada nieuczciwości. Przedstawiam przy tym kilka warunków bycia uczciwym i nieuczciwym, by ostatecznie pokazać, że w świetle materiału zebranego przez współczesną psychologię warunki te nie są, jak się zdaje, spełniane. $\mathrm{Na}$ tej podstawie dochodzę do wniosku, że większość ludzi nie jest ani uczciwa, ani nieuczciwa. Na koniec przedstawiam pewne szczegóły swojej koncepcji cech mieszanych, dotyczącej tych cech, które - jak twierdzę - większość ludzi faktycznie posiada.
\end{abstract}

Spis treści

I. Oszukiwanie i zachowanie

2. Oszukiwanie i motywacja

3. Oszukiwanie, uczciwość i nieuczciwość

4. Wersja alternatywna - cechy mieszane 
łównym przedmiotem moich ostatnich badań były empiryczne

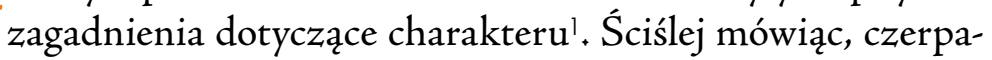
łem $z$ bogatego dorobku psychologii minionych 50 lat, badającej myśli i zachowania istotne pod względem moralnym. Oto jeden z wniosków, do których doszedłem:

(TI) Niewielu ludzi posiada dziś którąkolwiek z tradycyjnych cnót moralnych ${ }^{2}$.

Tego rodzaju cnoty to na przykład współczucie, szczerość czy odwaga. Wniosek ten nie jest zaskakujący - na jego poparcie wystarczy obejrzeć wieczorne wiadomości lub przejrzeć dowolny podręcznik historii. Ale oprócz tego twierdzę również, że:

(T2) Niewielu ludzi posiada dziś którąkolwiek z tradycyjnych moralnych wad.

Tego rodzaju wady to na przykład okrucieństwo, nieuczciwość czy tchórzostwo.

Twierdzenia (TI) i (T2) są bardzo ogólne i nie mogę ich w tym miejscu należycie uzasadnić. Zamiast tego skupię się wyłącznie na jednej sferze naszego życia moralnego, a mianowicie na oszukiwaniu i motywacji do niego, i zbadam pokrótce, czy istnieje jakiekolwiek empiryczne uzasadnienie dla odpowiadającej tej sferze cnoty uczciwości i wady nieuczciwości. Wnioski, do jakich dochodzę na tym polu, dotyczą również innych dziedzin moralności, choć nie będę w stanie tego tutaj pokazać.

W pierwszej części tego artykułu przyjrzę się głównym badaniom nad oszukiwaniem, w drugiej zaś badaniom nad stojącą za

Efektem tych badań są moje dwie książki: Moral Character: An Empirical Theory, Oxford 2013; Character and Moral Psychology, Oxford 2014.

2 Ta teza powinna ograniczać się wyłącznie do ludzi z kręgu zachodnich społeczeństw industrialnych, ponieważ badania psychologiczne publikowane w głównych periodykach przeprowadzane są niemal zawsze na populacji europejskiej bądź północnoamerykańskiej. Obraz charakteru, jaki kreślę, może mieć ogólniejsze zastosowanie, ale by można było swobodnie postawić taką tezę, należałoby przeprowadzić dalsze badania. 
nim motywacją. W części trzeciej nakreślę ogólny zarys kilku warunków uczciwości i nieuczciwości oraz wyjaśnię, dlaczego w świetle obecnych dowodów psychologicznych - warunki te raczej nie są dziś spełniane. Wreszcie w czwartej części zaprezentuję pewne szczegóły swojej koncepcji cech mieszanych (Mixed Trait Approach) dotyczącej tych cech, które - jak twierdzę - większość ludzi faktycznie posiada.

\section{Oszukiwanie i zachowanie}

Przez „oszukiwanie” rozumiem zachowanie celowo łamiące reguły obowiązujące w danej sytuacji (związanej lub niezwiązanej $z$ moralnością), mające na celu osiągnięcie korzyści na drodze podstępu. Sportowcy stosujący doping celowo i podstępnie łamią reguły obowiązujące w danej dyscyplinie, by osiągnąć przewage nad rywalami; podatnicy zaniżający swoje przychody celowo łamią reguły podatkowe, by osiągnąć korzyści majątkowe na drodze oszustwa; studenci, którzy przepisują prace, celowo łamią zasady obowiązujące na uczelni, by uzyskać lepszy stopień, przedstawiając cudzą pracę jako swoją, itd. Zwróćmy uwagę, że z podanego wyżej określenia nie wynika, iż to oszust musi zawsze odnieść korzyść. Na przykład uczeń może pozwolić koledze przepisać swoją prace domową nie dla własnej korzyści, lecz dla korzyści tego kolegi ${ }^{3}$.

Serwisy informacyjne w Stanach Zjednoczonych pełne są historii oszustw. W świecie finansów za winne ich popełnienia zostały uznane tak wybitne postacie, jak Charles Rangel, Bernard Madoff czy Kenneth Lay. Za doping zawieszano gwiazdy futbolu, koszykówki czy kolarstwa. Wśród znanych osobistości

3 Nie twierdzę, że podane przeze mnie określenie oszukiwania wyczerpuje jego konieczne bądź wystarczające warunki. Być może są przypadki oszukiwania, w których ktoś łamie zasady, ale nie robi tego celowo. Niewykluczone, że można też oszukiwać otwarcie, bez uciekania się do podstępu. Moim celem było wyłącznie podanie określenia, które obejmie większość przypadków znanych $z$ życia i psychologicznej literatury tematu. 
na porządku dziennym są zdrady małżeńskie - Bill Clinton, John F. Kennedy, Tiger Woods, Eliot Spitzer, John Edwards, Elizabeth Taylor, książę Karol, Hugh Grant, Kobe Bryant czy Jude Law to tylko niektóre $z$ nazwisk na długiej liście.

Bardziej systematyczne próby udokumentowania oszustw można znaleźć w pokaźnej literaturze naukowej dotyczącej oszustw akademickich. Według trzech ostatnich badań przeciętny odsetek studentów dopuszczających się oszustw na uczelniach wyniósł odpowiednio 70\%, 86\% i 60\% ${ }^{4}$. Wszystko wskazuje na to, że odsetek ten dramatycznie rośnie. Suzanne Ogilby twierdzi, że odsetek studentów, którzy przyznali się do oszustw, wzrósł od $23 \%$ w 1940 roku do $84 \%$ w roku $1982^{5}$. Jednak według jednego z badań, spośród studentów, którzy przyznali się do oszukiwania, jedynie około $3 \%$ donosi, że zostało złapanych ${ }^{6}$.

4 Zob. H. Klein i in., Cheating during the College Years: How Do Business Students Compare?, „Journal of Business Ethics” 72 (2007), s. 197-206; D. MCCABE, K. Butterfield, L. Treviño, Academic Dishonesty in Graduate Business Programs: Prevalence, Causes, and Proposed Action, „Academy of Management Learning and Education" 5 (2006), s. 294-305; C. Rokovski, E. Levy, Academic Dishonesty: Perceptions of Business Students, „College Student Journal” 4I (2007), s. 466-48I.

5 Ogilby S.M., The Ethics of Academic Behavior: Will it Affect Professional Behavior? "Journal of Education for Business" 7I (1995), s. 92-96.

6 A. Singhal, Factors in Students' Dishonesty, „Psychological Reports” 5 I (I982), s. 775-780. Dodatkowe dane nt. oszukiwania na uczelni zob. C. SMith, E. Ryan, D. Diggins, Moral Decision Making: Cheating on Examinations, "Journal of Personality" 40 (I972), s. 644 i 646; V. HaInes i in., College Cheating: Immaturity, Lack of Commitment, and the Neutralizing Attitude, "Research in Higher Education" 25 (1986), s. 345; D. McCabe, L. Treviño, Academic Dishonesty: Honor Codes and Other Contextual Influences, "Journal of Higher Education” 64 (1993), s. 522-538; ciż, Individual and Contextual Influences on Academic Dishonesty: A Multicampus Investigation, "Research in Higher Education” 38 (1997), s. 379-396; P. Faulkender i in., The Case of the Stolen Psychology Test: An Analysis of an Actual Cheating Incident, „Ethics \& Behavior” 4 (1994), s. 209-2I7; D. McCabe, L. Treviño, K. Butterfield, Cheating in Academic Institutions: A Decade of Research, „Ethics \& Behavior” II (200I), s. 219-232; E. Anderman, T. Murdock (eds.), Psychology of Academic Cheating, Amsterdam 2007; K. Williams, C. Nathanson, D. Paulhus, Identifying and Profiling Scholastic Cheaters: Their Personality, Cognitive Ability, and Motivation, ,Journal of Experimental Psychology: Applied" i6 (2010), s. 293-307; M. Simkin, S. McLeod, Why Do College Students Cheat?, "Journal of Business Ethics" 94 
By nie poprzestawać na uśrednionych wynikach, przytoczę dwa bardziej szczegółowe badania. Sunčana Taradi i jej współpracownicy przeprowadzili ankietę wśród chorwackich studentów medycyny na temat oszukiwania. Spośród 472 badanych jedynie trzech odpowiedziało, że nie dopuściło się żadnego spośród dziewięciu rodzajów oszustw wymienionych w kwestionariuszu, podczas gdy 78\% przyznało, że często dopuszczało się przynajmniej jednego $z$ nich ${ }^{7}$. Na przykład $94 \%$ badanych przyznało, że przynajmniej raz „zdobyło pytania testowe od osób, które już zdawały egzamin”, ale jedynie $5 \%$ spośród nich uznało to za poważne oszustwo, podczas gdy $28 \%$ nie uznało tego wcale za oszustwo, a $46 \%$ za drobne oszustwo. Podobnie 90\% badanych przyznało się do „przepisywania od kolegi podczas egzaminu za jego wiedzą”, ale jedynie $4 \%$ spośród nich uznało to oszustwo za poważne. Mało tego, aż $68 \%$ ankietowanych przyznało się do „zdawania egzaminu za kogoś innego”, ale jedynie $33 \%$ spośród nich uznało, że to poważne oszustwo ${ }^{8}$.

Jeszcze bardziej szczegółowe badanie, przeprowadzone przez Patricię Faulkender i jej współpracowników, dotyczyło przypadku oszustwa na kursie wprowadzenia do psychologii na Uniwersytecie w Południowym Missisipi. Skradziono tam wówczas i powielono drugi test semestralny. W porównaniu z pierwszym egzaminem studenci ukończyli go szybciej i uzyskali dużo lepsze wyniki. Władze uczelni wszczęły oficjalne dochodzenie i zarządziły obowiązkowe powtórzenie egzaminu. Faulkender przeprowadziła anonimową ankietę wśród 633 zapisanych na kurs studentów 22\% przyznało się do oszukiwania przy pomocy kserokopii testu, a kolejne $35 \%$ odpowiedziało, że zdobyłoby odbitkę, gdyby miało do tego okazję. Tak więc $57 \%$ badanych było wysoce skłonnych do oszukiwania na egzaminie, gdyby udało się im uniknąć konsekwencji. Podobnie $49 \%$ badanych studentów matematyki na

(2010), s. 44I-453; J. O'Rour Ke i in., Imitation is the Sincerest Form of Cheating: The Influence of Direct Knowledge and Attitudes on Academic Dishonesty, „Ethics $\&$ Behavior" 20 (20I0), s. 53 i 55; S. TARAdi i in., Students Come to Medical Schools Prepared to Cheat: A Multi-Campus Investigation, "Journal of Medical Ethics" 36 (2010), s. 666-670.

7 Tamże, s. 667.

8 Tamże, s. 668 . 
tym samym uniwersytecie (w tym przypadku nie było dowodów na oszukiwanie) przyznało, że skorzystałoby ze skradzionej kopii egzaminu, gdyby miało taką okazję

Wyniki tych i innych badań nad oszukiwaniem na uczelniach pokazują, że jest to zjawisko powszechne, przynajmniej wśród studentów na Zachodzie. Jak stwierdza Valerie Haines i jej współpracownicy w swoim często cytowanym artykule, takie oszukiwanie w kręgach studenckich ,jest jak epidemia”, i przypuszczam, że większość badaczy by się z nią zgodziła ${ }^{10}$. Ale oszukiwanie na uczelni samo w sobie nie jest niczym niezwykłym. Przeciwnie, badania sugerują, że większość ludzi jest skłonna oszukiwać w rozmaitych sytuacjach - na uczelni, w sporcie, w sprawach finansowych i innych. Co więcej, wiele publikacji pokazało, że skłonność tę można badać w kontrolowanych warunkach eksperymentalnych. Wspomnę tutaj pokrótce o dwóch spośród takich badań ${ }^{11}$.

9 P. Faulkender i in., The Case of the Stolen Psychology Test..., dz. cyt., s. 2 I2.

10 V. Haines i in., College Cheating..., dz. cyt., s. 342. Murdock i Stevens opisują oszukiwanie jako „szerzące się”; T. Murdock, J. Stephens, Is Cheating Wrong? Students' Reasoning about Academic Dishonesty [w:] E. Anderman, T. Murdock (eds.), Psychology of Academic Cheating, Amsterdam 2007, s. 248, zaś DeSteno i Valdesolo używają takich określeń jak „,szerzące się”, „powszechne” i „oczekiwane na podstawie doświadczenia” [D. DeSteno, P. Valdesolo, Out of Character: Surprising Truths about the Liar, Cheat, Sinner (and Saint) Lurking in All of Us, New York 20II, s. I73].

11 Oprócz tych badań zob. również R. Dienstbier, P. Munter, Cheating as a Function of the Labeling of Natural Arousal, "Journal of Personality and Social Psychology" I7 (I97I), s. 208-213; J. Houston, Curvilinear Relationships among Anticipated Success, Cheating Behavior, Temptation to Cheat, and Perceived Instrumentality to Cheat, , Journal of Educational Psychology" 70 (I978), s. 758762; J. Bloodgood, W. Turnley, P. Mudrack, The Influence of Ethics Instruction, Religiosity, and Intelligence on Cheating Behavior, "Journal of Business Ethics" 82 (2008), s. 557-571; K. VoHs, J. Schooler, The Value of Believing in Free Will: Encouraging a Belief in Determinism Increases Cheating, ,Psychological Science" I9 (2008), s. 49-54; N. Mazar, O. Amir, D. Ariely, The Dishonesty of Honest People: A Theory of Self-Concept Maintenance, „Journal of Marketing Research" 45 (2008), s. 633-644; F. Gino, L. Pierce, Dishonesty in the Name of Equity, „Psychological Science” 20 (2009), s. II53-II60; N. Mead i in., Too Tired to Tell the Truth: Self-Control Resource Depletion and Dishonesty, ,Journal of Experimental Social Psychology" 45 (2009), s. 594-597; C. ZHong, V. Bohns, F. Gino, Good Lamps are the Best Police: Darkness Increases Dishonesty and SelfInterested Behavior, „Psychological Science” 2I (20I0), s. 3I I-3I4; O. Gillath 
Edward Dienner i Mark Wallbom rozdali badanym anagramy, spośród których jedynie połowę można było rozwiązać w przeciągu 5-minutowego limitu czasu. Następnie eksperymentator mówił, że musi wyjść na Io minut, żeby pomóc innym uczestnikom badania, i ustawiał czasomierz na 5 minut, polecając badanemu „zaprzestanie dalszego rozwiązywania łamigłówki po usłyszeniu dzwonka"12. Przez lustro weneckie obserwowano, czy osoba badana faktycznie przerywała pracę po 5 minutach. 7I\% badanych kontynuowało rozwiązywanie zadania po usłyszeniu $\mathrm{d} z$ wonka ${ }^{13}$. Tworzyli oni grupę kontrolną; do grupy eksperymentalnej przejdę w dalszej części artykułu.

W jednym $z$ warunków eksperymentalnych badania przeprowadzonego przez Lisę Shu i jej współpracowników uczestnicy otrzymywali io dolarów, formularz z 20 zadaniami i kartę wyników, na której mieli samodzielnie zapisywać punktację. Badanym powiedziano, że mają 4 minuty na rozwiązanie zadań (była to celowo zbyt mała ilość czasu) i za każdą poprawną odpowiedź mogą zatrzymać 50 centów. W warunkach kontrolnych eksperymentator sprawdzał odpowiedzi i przydzielał pieniądze. W warunkach eksperymentalnych badani mieli sami liczyć liczbę poprawnych odpowiedzi i zapisywać ją w karcie wyników, a następnie zniszczyć arkusz testowy i wypłacić sobie stosowną kwotę. Eksperymentator niczego nie sprawdzał. Innymi słowy, w warunkach eksperymentalnych badani mogli zanotować dowolną ilość prawidłowych odpowiedzi i wypłacić sobie

$\mathrm{i}$ in., Attachment, Authenticity, and Honesty: Dispositional and Experimentally Induced Security Can Reduce Self- and Other-Deception, ,Journal of Personality and Social Psychology" 98 (20I0), s. 84I-855 oraz F. Gino, J. Margolis, Bringing Ethics into Focus: How Regulatory Focus and Risk Preferences Influence (Un) ethical Behavior, "Organizational Behavior and Human Decision Processes” II5 (20II), s. I45-I56. Można przytoczyć jeszcze szereg innych badań [przeglądu wcześniejszych spośród nich dokonuje A. Blasi w Bridging Moral Cognition and Moral Action: A Critical Review of the Literature, "Psychological Bulletin” 88 (I980), s. 2I-23].

12 E. Diener, M. Wallbom, Effects of Self-Awareness on Antinormative Behavior, "Journal of Research in Personality" Io (I976), s. I09.

13 Tamże, s. Iıo. 
dowolną ilość pieniędzy, a nikt nie mógł tego zweryfikować. Oto rezultaty ${ }^{14}$ :

+ Brak możliwości oszukania

+ Możliwość oszukania
7,97 poprawnych odpowiedzi (średnia grupy)

I3,22 poprawnych odpowiedzi (średnia grupy)

Trudno uwierzyć, że członkowie drugiej grupy byli aż w takim stopniu lepsi w rozwiązywaniu anagramów! Jest raczej oczywiste, że większość z nich wykorzystała okazję do bezkarnego oszustwa.

Podsumowując, choć w tej części artykułu przybliżyłem szczegóły jedynie czterech badań, są one reprezentatywne dla tego, co możemy znaleźć w literaturze przedmiotu. Oszukiwanie wydaje się powszechne i w odpowiednich okolicznościach większość z nas może się go dopuścić.

\section{Oszukiwanie i motywacja}

Dlaczego tak wielu spośród nas zbacza na drogę oszustwa? Jakie są najlepsze naukowe wyjaśnienia motywów stojących za tym zachowaniem? Na te pytania nie ma prostej odpowiedzi. Dana osoba może oszukiwać na różne sposoby $z$ tego samego powodu, a dwie osoby mogą oszukiwać w ten sam sposób z całkiem innych powodów.

By zbliżyć się do zrozumienia motywacji stojącej za oszukiwaniem, zacznę od ważnej uwagi: większość ludzi - jak twier$\mathrm{d} z \mathrm{i}$ - uważa oszukiwanie za złe w ogóle oraz w poszczególnych przypadkach, takich jak przepisywanie testu od drugiej osoby. Wydaje się więc, że istnieją właściwe przekonania moralne i może

14 L. Shu, F. Gino, M. Bazerman, Dishonest Deed, Clear Conscience: When Cheating Leads to Moral Disengagement and Motivated Forgetting, „Personality and Social Psychology Bulletin" 37 (201I), s. 339. 
z nich wypływać motywacja do nieoszukania, gdy nadarzy się okazja.

Jednym ze sposobów na zbadanie występowania i roli przekonań moralnych w odniesieniu do oszukiwania jest przeprowadzenie eksperymentów, w których manipuluje się wyrazistością tych przekonań. Dla przykładu, Nina Mazar i jej współpracownicy przeprowadzili eksperyment, w którym członków grupy kontrolnej poproszono najpierw o napisanie tytułów ro książek, które przeczytali w liceum (przypomnienie niedotyczące moralności), zaś członków grupy eksperymentalnej - o spisanie z pamięci Dziesięciu przykazań (przypomnienie dotyczące moralności). Następnie wszyscy badani rozwiązywali test składający się z 20 zadań w warunkach podobnych do tych $z$ eksperymentu Shu - ich wyniki były sprawdzane przez eksperymentatora albo badani wyrzucali arkusze testowe i oddawali eksperymentatorowi kartę ocen $z$ dowolną liczbą poprawnych odpowiedzi. Okazało się, że $\mathrm{w}$ warunkach nadzoru nie miało znaczenia, co przypominali sobie badani - średnia rozwiązanych zadań wyniosła 3,I. Natomiast w warunkach wyrzucania arkuszy testowych wskaźnik oszustw był wyraźnie wyższy (4,2 rozwiązanego zadania) u tych spośród badanych, którzy przypominali sobie przeczytane książki; jednak u tych nich, którzy przypominali sobie Dziesięć przykazań, średnia rozwiązanych zadań spadła do 2,8 , a więc najniżej w całym eksperymencie ${ }^{15}$.

Wnioski są dość oczywiste - dzięki przypomnieniu dotyczącemu moralności normy moralne stały się dla badanych wyrazistsze, przez co znacznie trudniej było im uzasadnić zły postępek, jakim jest oszustwo. Tak więc faktycznie istnieją przekonania zabraniające oszukiwania, ale często nie pamiętamy o nich lub nie jesteśmy ich świadomi, przynajmniej w pewnych sytuacjach etycznych ${ }^{16}$.

Badanie to może nie być przydatne do zapobiegania oszukiwaniu w realnych sytuacjach, ale odnosi się ono do istotnego

15 N. Mazar, O. Amir, D. Ariely, The Dishonesty of Honest People..., dz. cyt., s. 636 .

16 Tamże, s. 635. 
aspektu dyskusji nad oszukiwaniem na uczelniach, a mianowicie do wykorzystania kodeksu honorowego. Badania wykazały, że obecność kodeksu honorowego koreluje ze spadkiem liczby oszustw. Dla przykładu, w latach I990-I99i Donald McCabe i Linda Treviño odkryli, że na uczelniach, na których nie obowiązywał kodeks honorowy, do pomagania innym studentom podczas egzaminu przyznało się $28 \%$ badanych, podczas gdy na uczelniach $z$ kodeksem honorowym - zaledwie 9\%. Podobną tendencję zaobserwowano w przypadku plagiatowania (I8\% kontra $7 \%)$, ściągania (21\% kontra 7\%), niedozwolonej współpracy (39\% kontra $21 \%$ ) i innych rodzajów oszustw ${ }^{17}$. Badacze odkryli również, że by być skutecznym, kodeks honorowy nie może być jedynie - jak to ujęli - „fasadową dekoracją”, lecz musi być „właściwie stosowany i mocno zakorzeniony w kulturze studenckiej”18.

I rzeczywiście, wyraźny wpływ kodeksów honorowych na oszukiwanie został wykazany nawet w prostych warunkach laboratoryjnych. W kolejnym badaniu Mazar zmieniła warunki początkowe - zrezygnowała z przypominania, przez co jedynym wyróżnikiem warunków kontrolnych było sprawdzanie rozwiązań przez eksperymentatora. W warunkach wyrzucania arkuszy testowych dano badanym - tak jak poprzednio - sposobność do oszukania. Doszła jednak trzecia grupa badanych, która oprócz tego, że miała wyrzucić arkusze testowe, dostała do podpisania następującą deklarację: „Rozumiem, że badanie to podlega zasadom kodeksu honorowego MIT Uniwersytetu w Yale"19. Mazar

17 Zob. D. McCabe, L. Treviño, K. Butterfield, Cheating in Academic Institutions..., dz.cyt., s. 224. Zdaniem McCabe’a i Treviño zjawisko to częściowo tłumaczy fakt, iż „kodeksy honorowe wyraźniej definiują złe postępki. Przy jasnym określeniu złego postępku potencjalnym oszustom trudniej jest zracjonalizować i usprawiedliwić oszukiwanie, co prowadzi do jego rzadszego występowania" (tamże, s. 225).

18 Tamże, s. 224. Dalszą dyskusję i dane dotyczące kodeksów honorowych i oszukiwania zob. w D. McCabe, L. Treviño, Academic Dishonesty..., dz. cyt.; D. McCabe, L. Treviño, K. Butterfield, Cheating in Academic Institutions..., dz. cyt. oraz T. Thorkildsen, C. Golant, L. Richesin, Reaping What We Sow: Cheating as a Mechanism of Moral Engagement [w:] E. Anderman, T. Murdock (eds.), Psychology of Academic Cheating, Amsterdam 2007, s. I9I.

19 N. Mazar, O. Amir, D. Ariely, The Dishonesty of Honest People..., dz. cyt., s. 637 . 
stwierdziła, że nie było tu zagrożenia karą z zewnątrz, gdyż na żadnej z uczelni nie obowiązywał wówczas kodeks honorowy ${ }^{20}$. Oto wyniki²!

Rozwiązane zadania (0,5 dolara za poprawną odpowiedź)
Warunki kontrolne
Warunki wyrzucania arkuszy testowych
Warunki wyrzucania arkuszy testowych + kodeks honorowy

3,0

\author{
Rozwiązane zadania \\ (2 dolary za poprawną \\ odpowiedź)
}

Chociaż więc w trzeciej grupie nie zmieniło się nic w kwestii możliwości uniknięcia wykrycia, jej uczestnicy osiągali nawet wyniki nieznacznie gorsze niż badani w grupie kontrolnej. Nie skusiła ich również dodatkowa nagroda 2 dolarów za poprawną odpowiedź.

Przypuśćmy, że większość ludzi rzeczywiście uważa oszukiwanie za moralnie niewłaściwe $\mathrm{w}$ ogóle i/lub w różnych określonych przypadkach ${ }^{22}$. Jak więc wyjaśnić to, że pomimo występowania tych

20 Eksperyment powtórzono później na uczelni z surowym kodeksem honorowym i uzyskano podobne rezultaty (tamże).

21 Tamże. W badaniu, które przywoływałem w pierwszej części, Shu i jej współpracownicy również manipulowali rolą kodeksu honorowego, jednak badani z odpowiedniej grupy nie podpisywali go, tylko czytali. W warunkach niszczenia kart ocen bez kodeksu honorowego badani uzyskali średnio I3,22 poprawnych odpowiedzi, zaś w warunkach niszczenia kart i czytania kodeksu - I0,03. Mimo wszystko były to wyniki wyższe niż 7,97 poprawnych odpowiedzi w warunkach kontrolnych bez czytania kodeksu (L. SHU, F. Gino, M. Bazerman, Dishonest Deed, Clear Conscience..., dz. cyt., s. 339). Samo czytanie, a nie podpisywanie kodeksu honorowego, zapewne ma znaczenie, co wyjaśnię dokładniej w dalszej części tego artykułu.

22 Zob. V. Haines i in., College Cheating..., dz. cyt.; T. Murdock, J. Stephens, Is Cheating Wrong?..., dz. cyt., s. 229; F. Gino, S. Ayal, D. Ariely, Contagion and Differentiation in Unethical Behavior: The Effect of One Bad Apple on the Barrel, „Psychological Science” 20 (2009), s. 393-398; J. O'Rourke i in., Imitation is the Sincerest Form of Cheating..., dz. cyt., oraz D. DeSteno, P. Valdesolo, Out of Character..., dz. cyt., s. I73. 
przekonań oszukiwanie wciążjest powszechne? Na to pytanie nie ma jednoznacznej odpowiedzi. W różnych sytuacjach u różnych osób do głosu dochodzą różne motywy oszustwa. Postaram się jednak wymienić kilka ogólnych kategorii czynników motywacyjnych. Jednym $z$ takich czynników jest chęć uniknięcia porażki (i, co się z tym wiąże, zakłopotania bądź wstydu) ${ }^{23}$. Innym jest pragnienie osiągnięcia sukcesu bądź uzyskanie określonej przewagi nad konkurentami, zrealizowanie konkretnych celów lub osiągnięcie innych korzyści ${ }^{24}$. Jeszcze innym czynnikiem jest fakt, iż oszukiwanie (lub ryzyko bycia przyłapanym) dostarcza rozrywki lub jest ciekawe ${ }^{25}$.

Wszystkie te motywy można ogólnie określić jako egoistyczne; dla osoby oszukującej (w jej mniemaniu) wiążą się z nimi określone koszty i zyski w przypadku powodzenia. Z drugiej strony mamy przeciwne im normy moralne, które zabraniają oszukiwania. Gdy

23 Zob. np. C. Smith, E. Ryan, D. Diggins, Moral Decision Making..., dz. cyt;; S. Newstead, A. Franklyn-Stokes, P. Armstead, Individual Differences in Student Cheating, "Journal of Educational Psychology" 88 (I996), s. 233; T. Murdock, J. Stephens, Is Cheating Wrong?..., dz. cyt., s. 244;

T. Thorkildsen, C. Golant, L. Richesin, Reaping What We Sow..., dz. cyt., s. 193 oraz S. Rick, G. Loewenstein, Commentaries and Rejoinder to 'The Dishonesty of Honest People', "Journal of Marketing Research" 45 (2008), s. $645-653$.

24 Zob. np. C. Smith, E. Ryan, D. Diggins, Moral Decision Making..., dz. cyt.; S. Newstead, A. Franklyn-Stokes, P. Armstead, Individual Differences in Student Cheating, dz. cyt., s. 229-24I; T. Thorkildsen, C. Golant, L. Richesin, Reaping What We Sow..., dz. cyt., s. I92; T. Murdock, J. Stephens, Is Cheating Wrong?..., dz.cyt., s. 248; S. Rick, G. Loewenstein, Commentaries and Rejoinder..., dz.cyt., s. 646; K. Williams, C. Nathanson, D. Pauluus, Identifying and Profiling Scholastic Cheaters..., dz. cyt., s. 299-303; M. Simkin, S. McLeod, Why Do College Students Cheat?, dz. cyt.; D. DeSteno, P. Valdesolo, Out of Character..., dz. cyt., s. I72 oraz F. Gino, J. Margolis, Bringing Ethics into Focus..., dz. cyt. Podobne omówienie motywów oszukiwania zob. S. Newstead, A. Franklyn-Stokes, P. Armstead, Individual Differences in Student Cheating, dz. cyt. oraz D. McCabe, L. Treviño, K. Butterfield, Cheating in Academic Institutions..., dz.cyt., s. 228.

25 Zob. np. S. Tibbetts, Gender Differences in Students' Rational Decisions to Cheat, „Deviant Behavior” I8 (I997), s. 393-4I4; D. Nagin, G. Pogarsky, An Experimental Investigation of Deterrence: Cheating, Self-Serving Bias, and Impulsivity, „Criminology” 4I (2003), s. I67-194; T. Thor Kildsen, C. GolanT, L. Richesin, Reaping What We Sow..., dz.cyt., s. I83. 
zestawić ze sobą te dwa elementy, dojdziemy do naturalnego wniosku, że dana osoba będzie miała większą motywację do stosowania się do swoich norm moralnych, jeśli zbiór korzyści z oszukania w tej sytuacji nie przeważy w jej przekonaniu zbioru korzyści płynących z postąpienia w sposób moralnie słuszny. Z drugiej strony, jeśli osoba ta uzna, że korzystniej jest oszukać niż postąpić moralnie słusznie, będzie mieć większą ogólną motywację do oszukania.

Wniosek ten jest dość oczywisty - postępowanie w sposób moralnie słuszny $\mathrm{w}$ pewnych sytuacjach pozostaje $\mathrm{w}$ psychologicznym konflikcie $z$ działaniem, które - jak się zdaje - sprzyja własnej korzyści ${ }^{26}$. Okazuje się jednak, że zaprzeczają mu ostatnie świadectwa empiryczne. Przede wszystkim na jego podstawie można przewidywać, że skoro ludzie oszukują, bo sądzą, iż oszukiwanie przyniesie im korzyści i uda im się uniknąć wykrycia, to nie będą oszukiwać trochę, lecz będą starali się osiągnąć dla siebie jak najwięcej, tj. na przykład zmaksymalizować zysk finansowy lub osiągnąć jak największą przewagę nad rywalami w danej dyscyplinie sportu.

Wróćmy jednak do wyników uzyskanych przez Mazar - badani w warunkach kontrolnych uzyskiwali średnio 3,I poprawnych odpowiedzi, podczas gdy w warunkach eksperymentalnych - 4,2, jednak do rozwiązania było aż 20 zadań! Skoro w grupie, która wyrzucała arkusze testowe, eksperymentator nie mógł zauważyć różnicy i badani dobrze wiedzieli, że ich oszustwo nie wyjdzie na jaw, czemu nie chcieli bardziej zawyżyć swoich wyników i uzyskać dla siebie większych korzyści finansowych? Podobnie było w badaniu $z$ kodeksem honorowym - grupa, która wyrzucała arkusze testowe i otrzymywała 0,50 dolara za rozwiązanie zadania, uzyskała wyższy przeciętny wynik (6,I poprawnych odpowiedzi)

26 Dobry przykład wykorzystania tej koncepcji przez psychologów w dyskusji na temat oszukiwania można znaleźć w C. Smith, E. Ryan, D. Diggins, Moral Decision Making..., dz. cyt. Jak zauważają autorzy, „zasady moralne nie są oczywiście jedynymi determinantami moralnego zachowania. Ważną rolę odgrywają również oczekiwania korzyści bądź kary. Osoba, która uważa oszukiwanie za niemoralne, może i tak dopuścić się oszustwa, jeśli oczekiwana korzyść będzie dostatecznie duża, podczas gdy osoba, która nie widzi w oszukiwaniu niczego złego, może powstrzymać się od popełnienia oszustwa w obawie przed karą" (tamże, s. 656). 
niż grupa, która również wyrzucała arkusze testowe, ale otrzymywała dwudolarową nagrodę ( 5 poprawnych odpowiedzi). Czemu ta druga grupa poprzestała na 5 poprawnych odpowiedziach $z 20$ możliwych? Mazar przeprowadziła kolejne badanie $z 4$ różnymi stawkami (0,10, 0,50, 2,50 i 5 dolarów). W porównaniu z grupą kontrolną stwierdzono pewną nieuczciwość w pierwszych dwóch grupach eksperymentalnych, ale nie w dwóch ostatnich ${ }^{27}$. W sumie w 6 eksperymentach wzięło udział 79I badanych i jedynie 5 spośród nich oszukało w maksymalnym stopniu ${ }^{28}$. Ich zachowanie wydaje nam się zrozumiałe; zachowanie pozostałych badanych jest zagadkowe ${ }^{29 !}$

Mazar wyjaśnia to w sposób następujący 30 (ja również przyjmuję tutaj to wyjaśnienie): uczestnicy badań byli na ogół skłonni do popełnienia oszustwa, dopóki nie zagrażało to ich obrazowi samych siebie jako ludzi uczciwych. Innymi słowy, badani oszukując, chcieli uzyskać dla siebie korzyści (w tym przypadku nagrodę pieniężną), jednak w pewnym momencie samoocena uczestników eksperymentu jako uczciwych ludzi powstrzymywała ich przed oszukiwaniem.

To wszystko skłania do skorygowania prostego wniosku na temat motywacji stojącej za oszukiwaniem. Nie jest po prostu tak, że większość ludzi chce oszukiwać, gdy koszty stosowania się do odpowiednich norm moralnych zakazujących oszukiwania przeważają (w wyraźny sposób) zyski. Jest raczej tak, że ludzie

27 N. Mazar, O. Amir, D. Ariely, The Dishonesty of Honest People..., dz. cyt., s. 642 .

28 Tamże, s. 643.

29 Podobne wyniki zob, również K. Vohs, J. Schooler, The Value of Believing in Free Will..., dz.cyt., s. 52; F. Gino, S. Ayal, D. Ariely, Contagion and Differentiation in Unethical Behavior..., dz. cyt.; F. Gino i in., Unable to Resist Temptation: How Self-Control Depletion Promotes Unethical Behavior, „Organizational Behavior and Human Decision Processes" II5 (201I), s. I9I-203; N. Mead i in., Too Tired to Tell the Truth..., dz. cyt., s. 595-596; C. Zhong, V. Bohns, F. Gino, Good Lamps are the Best Police..., dz.cyt., s. 3I2; F. Gino, J. Margolis, Bringing Ethics into Focus..., dz. cyt. oraz L. Shu, F. Gino, M. Bazerman, Dishonest Deed, Clear Conscience..., dz. cyt.

30 N. Mazar, O. Amir, D. Ariely, The Dishonesty of Honest People..., dz. cyt.; ciż, More Ways to Cheat: Expanding the Scope of Dishonesty, ,Journal of Marketing Research" 45 (2008), s. 650-653. 
chcą oszukiwać i jednocześnie chcą w największym możliwym stopniu wydawać się moralnymi zarówno innym ludziom, jak i sobie. Innymi słowy, ludzie zazwyczaj troszczą się o to, by być moralnymi, i pragną myśleć o sobie w ten sposób ${ }^{31}$, a jest to trudne, gdy jednocześnie agresywnie oszukują, skoro tylko nadarzy się do tego okazja ${ }^{32}$.

Rozwinę teraz tę myśl. Na początku tej części przytaczałem badania Dienera i Wallboma, w których 7I\% uczestników oszukiwało, przekraczając 5-minutowy limit czasu na rozwiązanie anagramu. Były to, jak wspominałem, wyniki grupy kontrolnej. W grupie eksperymentalnej badanych posadzono naprzeciwko lustra weneckiego tak, że „widzieli siebie, gdy tylko podnieśli wzrok" 33 . W tych warunkach oszukiwało jedynie $7 \%$ badanych $^{34}$. To uderzająca różnica. Postaram się ją wyjaśnić poniżej.

Z pewnością badani w grupie kontrolnej mieli pewne normy moralne zakazujące oszukiwania, które były dla nich w jakimś stopniu istotne - $\mathrm{w}$ końcu powiedziano im wprost i to kilkukrotnie, by nie przekraczali 5 minut, a mimo to większość $z$ nich to zrobiła. Czemu? Bo korzyści płynące dla nich z oszustwa przeważyły korzyści płynące $z$ postąpienia słusznie i nie istniało praktycznie ryzyko zostania przyłapanym, gdyż eksperymentator opuszczał pomieszczenie. Co jednak z zagrożeniem, jakie tego rodzaju zachowanie niesie dla podtrzymania obrazu samego siebie jako osoby uczciwej? Z pewnością trudno byłoby zachować takie pojęcie o sobie w przypadku kontynuowania pracy po usłyszeniu dzwonka.

Tutaj dochodzi do głosu coś w rodzaju oszukiwania samego siebie. Jeśli można (podświadomie) powstrzymać się od zestawienia

31 Badania związane ze stopniem i wagą myślenia o sobie jako uczciwym człowieku zob. A. Gordon, A. Miller, Perspective Differences in the Construal of Lies: Is Deception in the Eye of the Beholder?, "Personality and Social Psychology Bulletin" 26 (2000), s. 47.

32 Podobne omówienie kłamania w przeciwieństwie do oszukiwania zob. tamże, s. $46-47$.

33 E. Diener, M. Wallbom, Effects of Self-Awareness..., dz. cyt., s. Iog. W grupie eksperymentalnej manipulowano również dźwiękiem, by podnieść samoświadomość badanych.

Tamże, s. I Io. 
popełnianego właśnie oszustwa $z$ własnymi normami moralnymi, zagrożenie dla obrazu samego siebie jest mniejsze. Dlatego właśnie pozornie nieistotna zmienna jak ustawienie lustra może mieć tak drastyczny wpływ na zachowanie. Lustro zostawia człowiekowi dużo mniej miejsca do ukrycia się. Przy zwiększonej samoświadomości różnica pomiędzy tym, czego wymagają przekonania moralne, a pokusą do oszukania staje się szczególnie wyraźna, przez co dużo trudniej przekonać samego siebie, że wciąż jest się uczciwym człowiekiem.

To może również pomóc odpowiedzieć na pytanie, dlaczego wyrazistość normy moralnej, na przykład w eksperymencie z przypominaniem sobie Dziesięciu przykazań, może mieć taki wpływ na stosowanie się do tej normy. Częściowo można to wytłumaczyć po prostu w ten sposób, że zwiększona wyrazistość normy moralnej znacznie zwiększa motywację do stosowania się do niej. Możemy jednak, jak sądzę, powiedzieć również, że zwiększona wyrazistość jeszcze bardziej utrudnia podjęcie działań, które mogłyby zagrozić obrazowi samego siebie jako osoby uczciwej. Jak pisze Mazar, „gdy standardy moralne są łatwej dostępne, ludzie muszą być bardziej gotowi na zmierzenie się ze znaczeniem swoich działań i przez to postępować uczciwiej”35.

Warto jeszcze zwrócić uwagę na dwa aspekty ważności myślenia o sobie samych jako o ludziach uczciwych. Po pierwsze, wyjaśnienia tego nie należy rozciągać zbyt szeroko. Nie ulega wątpliwości, że są ludzie, którzy agresywnie oszukują. Jeśli korzyści płynące $z$ oszustwa wydadzą im się bardzo duże (inaczej niż w eksperymentach, w których stawką była zaledwie niewielka kwota pieniężna), mogą one przeważyć zarówno nad motywacją do postąpienia $\mathrm{w}$ zgodzie $z$ normami moralnymi, jak i motywacją do podtrzymania obrazu samych siebie jako ludzi uczciwych ${ }^{36}$. Tacy ludzie mogą wówczas przyznać, że postąpili nieuczciwie, ale twierdzić zarazem, że warto było tak zrobić.

35 N. Mazar, O. Amir, D. Ariely, The Dishonesty of Honest People..., dz. cyt., s. 635.

36 Dyskusję na ten temat zob. tamże, s. 642 oraz tychże, More Ways to Cheat..., $\mathrm{d} z$. cyt., s. 65I. Zob. też S. Rick, G. Loewenstein, Commentaries and Rejoinder..., dz. cyt., s. 646 . 
Po drugie, oszukiwanie samego siebie jest tylko jednym ze sposobów na podtrzymanie własnego wizerunku człowieka uczciwego pomimo dokonania oszustwa. Inną powszechną strategią jest racjonalizacja swojego zachowania. Ktoś na przykład może powiedzieć, że przepisanie pracy domowej od kolegi nie jest tak naprawdę niczym złym. Tak właśnie może być w przypadku chorwackich studentów medycyny, z których większość przyznała się do wielokrotnego oszukiwania, nie uznając jednak zdobywania pytań testowych od osób, które już zdawały egzamin, za poważne oszustwo ${ }^{37}$. Inną próbą racjonalizacji własnego zachowania jest wykorzystywanie dwuznaczności i przeciwstawianie pewnych kategorii innym w celu takiego sklasyfikowania własnego zachowania, by nie wydawało się ono moralnie problematyczne ${ }^{38}$.

Jeszcze inną strategią podtrzymania obrazu samego siebie jest zmniejszenie bądź zaprzeczenie własnej odpowiedzialności za oszustwo, na przykład poprzez stwierdzenie, że wszyscy tak postępują. I faktycznie, to, w jakim stopniu - zdaniem danego studenta - inni studenci oszukują, jest jednym z głównych czynników pozwalających przewidzieć prawdopodobieństwo, z jakim on również dopuści się oszustwa ${ }^{39}$. Bez wątpienia stosowane są również inne strategie, takie jak zaprzeczanie, że w ogóle doszło do oszustwa, czy obwinianie oskarżyciela ${ }^{40}$.

37 Jak pisze Taradi, „większość studentów nie uważała swoich oszukańczych działań za coś niezwykłego czy moralnie złego" (S. TARAdi i in., Students Come to Medical Schools..., dz. cyt., s. 669).

38 Zob. N. Mazar, O. Amir, D. Ariely, The Dishonesty of Honest People..., dz. cyt.

39 Zob. C. Smith, E. Ryan, D. Diggins, Moral Decision Making..., dz. cyt., s. 655; V. Haines i in., College Cheating..., dz. cyt., s. 350-35I; D. McCabe, L. Treviño, Academic Dishonesty..., dz. cyt., s. 527-528 i 532-533; ciż, Individual and Contextual Influences on Academic Dishonesty..., s. 383-384 i 39I-392; S. Newstead, A. Franklyn-Stokes, P. Armstead, Individual Differences in Student Cheating, dz. cyt., s. 233 i 239; D. McCabe, L. Treviño, K. Butterfield, Cheating in Academic Institutions..., dz. cyt., s. 222; S. TARAdi i in., Students Come to Medical Schools..., dz. cyt., s. 669; D. DeSteno, P. Valdesolo, Out of Character..., dz. cyt., s. I72-I75 i zwłaszcza J. O’Rourke i in., Imitation is the Sincerest Form of Cheating..., dz. cyt.

40 Wszystkie te strategie to sposoby na „neutralizację” bądź „moralne wycofanie się". Skupiłem się tutaj na strategiach stosowanych po dopuszczeniu się działania uważanego przez sprawcę za złe, natomiast neutralizacja może 
Przed zakończeniem tego punktu chciałbym dodać jedną poprawkę do nakreślonego tutaj obrazu motywacji do oszukiwania. Ta motywacja wiązała się $z$ egoistycznymi korzyściami dla osoby dopuszczającej się oszustwa. Ale nie każde oszustwo obliczone jest na bezpośrednią korzyść tego, kto oszukuje. Przykładowo w środowisku akademickim wielu studentów pozwala kolegom przepisywać prace domowe bądź spisywać odpowiedzi podczas egzaminu. Stephen Newstead i jego współpracownicy przebadali 943 studentów i stwierdzili, że I $4 \%$ spośród tych, którzy przyznali się do oszukiwania, jako jeden z powodów podawali "chęć pomocy koledze"4l. Badacze odkryli również, że I6\% tych studentów napisało za kogoś innego pracę semestralną, zaś $29 \%$ oceniło pracę kolegi wyżej, niż na to zasługiwała ${ }^{42}$. Takie postępowanie może $z$ pewnością znacznie pomóc komuś innemu, ale nie bezpośrednio oszustowi. $Z$ tego oczywiście nie wynika, że za oszukiwaniem zorientowanym na innych stoją ostatecznie altruistyczne motywy. Do tego zagadnienia powrócę w następnym punkcie.

pojawić się przed, w trakcie lub po takim zachowaniu (V. Haines i in., College Cheating..., dz. cyt., s. 344 i 346 oraz L. Shu, F. Gino, M. Bazerman, Dishonest Deed, Clear Conscience..., dz. cyt., s. 330-332). Związaną z tym dyskusję w kontekście oszukiwania zob. V. Haines i in., College Cheating..., dz. cyt.; P. Faulkender i in., The Case of the Stolen Psychology Test..., dz. cyt., s. 215; S. Newstead, A. Franklyn-Stokes, P. Armstead, Individual Differences in Student Cheating, dz. cyt., s. 229; D. McCabe, L. Treviño, K. Butterfield, Cheating in Academic Institutions..., dz. cyt., s. 227; T. Murdock, J. Stephens, Is Cheating Wrong?..., dz. cyt., s. 233-248; M. Simkin, S. McLeod, Why Do College Students Cheat?, dz. cyt., s. 444; J. O'Rourke i in., Imitation is the Sincerest Form of Cheating..., dz. cyt. oraz S. Taradi i in., Students Come to Medical Schools..., dz. cyt., s. 669. Ogólniejsze omówienie neutralizacji i moralnego wycofania się zob. zwłaszcza G. Sykes, D. Matza, Techniques of Neutralization: A Theory of Delinquency, "American Sociological Review” 22 (1957), s. 664-670; A. BAndura i in., Mechanisms of Moral Disengagement in the Exercise of Moral Agency, "Journal of Personality and Social Psychology" 7I (1996), s. 364-374; T. Murdock, J. Stephens, Is Cheating Wrong?..., dz. cyt. oraz L. Shu, F. Gino, M. Bazerman, Dishonest Deed, Clear Conscience..., dz. cyt.

41 S. Newstead, A. Franklyn-Stokes, P. Armstead, Individual Differences in Student Cheating, dz. cyt., s. 233.

42 Tamże, s. 232. 
Na razie nakreśliłem obraz motywacji do oszukiwania poparty licznymi nowymi badaniami, który powinien mieć również zastosowanie do rzeczywistych przypadków oszukiwania.

\section{Oszukiwanie, uczciwość i nieuczciwość}

Dla mnie nikt, kto prezentuje motywację i zachowania opisane w poprzednich dwóch punktach, w oczywisty sposób nie jest uczciwy (w odniesieniu do oszukiwania). Jednocześnie jednak, choć być może w sposób mniej oczywisty, nie jest też nieuczciwy (znów - w odniesieniu do oszukiwania). By uzasadnić oba te twierdzenia, nakreślę różne wymogi, jakie ktoś musi spełnić, aby można go było nazwać - choćby w niewielkim stopniu - uczciwym bądź nieuczciwym.

Najpierw jednak przytoczę jeszcze jedno badanie, które spaja wiele wątków dotychczasowej dyskusji na temat oszukiwania i pomoże się skupić na ocenie moralnego charakteru ludzi. W kolejnym badaniu Shu i jej współpracowników obok grupy kontrolnej również była grupa wyrzucająca arkusze testowe oraz warunki $z$ kodeksem honorowym i bez niego. Tym razem jednak Shu dodała kolejny wariant $-\mathrm{w}$ jednej $z$ grup badani czytali kodeks honorowy, ale nie podpisywali go. Dodatkowo eksperymentatorzy potajemnie oznaczyli testy, by można je było później wydobyć z pojemnika i porównać z kartami ocen. W ten sposób mogli nie tylko dowiedzieć się, jaka była średnia w każdej grupie, lecz również, kto oszukiwał, a kto nie. Wreszcie, w końcowym kwestionariuszu wypełnianym po badaniu uczestnicy musieli (między innymi) odpowiedzieć na kilka pytań sprawdzających, co zapamiętali z treści kodeksu honorowego. Oto niektóre wyniki ${ }^{43}$ :

43 L. Shu, F. Gino, M. Bazerman, Dishonest Deed, Clear Conscience..., dz. cyt., s. $34 \mathrm{I}$. 
Brak możliwości oszukania

\begin{abstract}
Deklarowana liczba rozwiązanych zadań
\end{abstract}

\author{
Rzeczywista \\ liczba rozwiąz- \\ anych zadań
}

Zapamiętana treść kodeksu honorowego

\author{
Bez kodeksu \\ honorowego \\ Czytanie kodeksu \\ honorowego \\ Podpisanie kodeksu \\ honorowego
}

7,79

7,39

7,38

7,79

7,39

7,38

Możliwość oszukania

Deklarowana
liczba rozwiáz-
anych zadań

Bez kodeksu

honorowego

Czytanie kodeksu

honorowego

Podpisanie kodeksu honorowego
13,09

10,05

7,91

Rzeczywista
liczba rozwiąz-
anych zadań

Zapamiętana treść kodeksu honorowego

Jest tu sporo danych, więc pozwolę sobie zwrócić uwagę na wnioski, które uważam za najciekawsze. Przede wszystkim, w warunkach wyrzucania arkuszy testowych i braku kodeksu honorowego dopuszczano się wyraźnych oszustw (średnio I3,09 deklarowanych poprawnych odpowiedzi kontra 7,6I rzeczywistych). Swój wynik zawyżyło $57 \%$ badanych. Dla kontrastu, oszukiwanie było mniejsze w grupie, która czytała kodeks honorowy, ale i tak $37 \%$ uczestników zawyżyło swoje wyniki. Jednak w warunkach podpisania kodeksu honorowego swój wynik zawyżyła zaledwie jedna osoba spośród $22^{44}$. Tak więc o ile czytanie kodeksu honorowego pomogło nieco ograniczyć oszukiwanie, podpisanie go wyeliminowało je niemal zupełnie. Nie jest to być może zasko-

44 Tamże, s. 342. 
czenie - samo czytanie różni się od aktywnego zaangażowania się $\mathrm{w} \operatorname{coś}^{45}$.

Zwróćmy również uwagę, że choć średnia I3,09 w grupie, która wyrzucała arkusze testowe i nie dostała kodeksu honorowego, to wynik znacznie zawyżony w stosunku do rzeczywistego, to jest on i tak dużo niższy od maksymalnego, tj. 20 poprawnych odpowiedzi. Uczestnicy badania stracili około 3,50 dolara dodatkowego zysku, nie oszukując $\mathrm{w}$ takim stopniu, $\mathrm{w}$ jakim było to możliwe bez ryzyka ujawnienia. Zwróćmy wreszcie uwagę na średnią liczbę zapamiętanych punktów kodeksu honorowego w warunkach wyrzucania arkuszy testowych - w grupie, która tylko go czytała, była ona znacznie niższa $(2,82)$ niż w grupie, która musiała go podpisać $(4,27)$. Kolejne badanie potwierdziło tę tendencję ${ }^{46}$. Najwidoczniej wchodzi tu w grę pewna strategia racjonalizacji - badani mieli motywację do zapominania tego, co przeczytali, gdy stało to w sprzeczności z ich rzeczywistym zachowaniem $^{47}$.

Mając świeżo w pamięci te wyniki, podaję pierwszy wymóg uczciwości (w odniesieniu do oszukiwania; właśnie w takim odniesieniu będę mówił o tej cesze w dalszej części tej pracy):

(a) Osoba uczciwa, działając zgodnie ze swoim charakterem (in character), powstrzymuje się od regularnego oszukiwania w sytuacjach, których jest wolnym i dobrowolnym (willing) uczestnikiem i w których zasady są odpowiednie i sprawiedliwe, nawet jeśli poprzez oszustwo ma ona zapewnioną jakąś korzyść dla siebie ${ }^{48}$.

45 Tamże, s. 344. Zob, też D. McCabe, L. Treviño, Academic Dishonesty..., dz. cyt.; ciż, Individual and Contextual Influences on Academic Dishonesty..., dz. cyt. oraz N. Mazar, O. Amir, D. Ariely, The Dishonesty of Honest People..., dz. cyt.

46 L. Shu, F. Gino, M. Bazerman, Dishonest Deed, Clear Conscience..., dz. cyt., s. 336-339.

47 Tamże, s. 344.

48 Zob. np. R. Hursthouse, On Virtue Ethics, Oxford 1999, s. Io oraz R. Adams, A Theory of Virtue: Excellence in Being for the Good, Oxford 2006, s. I2I. 
Badania Shu pokazują, że wielu ludzi nie spełnia powyższego kryterium - ich uczestnicy oszukiwali, choć zgłosili się na ochotnika do udziału w eksperymencie mającym na celu poszerzenie wiedzy naukowej, gdzie zasady były jasno ustalone, sprawiedliwe i odpowiednie ${ }^{49}$. Można tu również przytoczyć wiele innych omówionych wcześniej eksperymentów, a są to zwykle - jak warto zwrócić uwagę - badania nad rzeczywistym oszukiwaniem, a nie tylko ankiety.

Możliwe, że twierdzenia (a) nie da się utrzymać jako ogólnej zasady. Być może są przypadki, w których ktoś dopuszczając się oszustwa w takich warunkach, może przynieść olbrzymie dobro moralne innym ludziom, na przykład przyjaciołom lub ukochanym. Weźmy na przykład szpiega, który przeniknął do pewnej firmy jako jej pracownik i musi zaburzyć standardowe procedury jej funkcjonowania, by pozyskać informacje niezbędne do powstrzymania ataku terrorystycznego. Taka osoba oszukuje firmę, ale nie wynika $z$ tego, że - rozpatrując rzecz w szerszej perspektywie - dopuszcza się czegoś moralnie złego lub postępuje w sprzeczności z moralną cnotą uczciwości.

Nie martwią mnie tego rodzaju kontrprzykłady dla twierdzenia (a). Można w nim dokonać stosownych poprawek. Najważniejsze, że poprawki te nie miałyby zastosowania do przypadków oszukiwania z eksperymentów Shu, Mazar i innych, ani też do innych badań nad oszukiwaniem na uczelniach, stosowaniem dopingu w sporcie czy malwersacjami.

49 Czy wielu ludzi ma dyspozycję do „regularnego” oszukiwania? Są mocne podstawy, by przypuszczać, że tak właśnie jest, gdyż w omówionych tu badaniach duża liczba uczestników oszukiwała w wielu różnych sytuacjach, gdy nadarzyła się po temu okazja. Co więcej, przypuszczam, że ci sami badani dopuszczaliby się regularnych oszustw, gdyby powtórnie stawiać ich w warunkach wyrzucania kart ocen i braku kodeksu honorowego, zwłaszcza że za pierwszym razem przekonali się, że oszustwo uszło im na sucho. Oba te twierdzenia wykraczają jednak poza dostępny materiał dowodowy. Po pierwsze dlatego, że nie badano tych samych uczestników w różnych sytuacjach; po drugie dlatego, że nie badano tych samych uczestników na przestrzeni czasu w tej samej, powtarzającej się sytuacji. 
A oto kolejny wymóg:

(b) Osoba uczciwa, działając zgodnie ze swoim charakterem, nie pozwala, by jej uczciwe postępowanie lub oszustwo było zależne - przynajmniej nie w wielu przypadkach - od obecności określonych czynników wzmagających lub hamujących, takich jak oczekiwane kary lub porażki, zwłaszcza gdy w grę wchodzą ważne kwestie moralne.

Innymi słowy, u osoby uczciwej oszukiwanie nie będzie się zmieniać w zależności od prawdopodobieństwa poniesienia kary lub narażenia się na wstyd $z$ powodu niepowodzenia ${ }^{50}$. Istnieją badania, które sugerują, że ludzie faktycznie tacy są.

Teraz przechodzę do wymogu motywacyjnego:

(c) Uczciwość osoby uczciwej zwykle skłania ją do powstrzymania się od oszukiwania głównie z powodów motywacyjnych godnych podziwu pod względem moralnym i zasługujących na moralne uznanie, a nie głównie z powodów motywacyjnych moralnie problematycznych lub neutralnych ${ }^{51}$.

Wspomniałem już, że uniknięcie przyłapania i kary jest jednym $z$ istotnych czynników powstrzymujących oszustwo. Kolejny, bardziej subtelny czynnik wiąże się z możliwością podtrzymania przekonania o samym sobie jako o człowieku uczciwym. To przynajmniej częściowo tłumaczyłoby, czemu uczestnicy eksperymentu Shu uzyskali średnio I3,09 poprawnych odpowiedzi zamiast 20. Jednak tego rodzaju motywacja nie jest oczywiście godna podziwu pod względem moralnym.

A oto kolejny wymóg.

50 Tutaj też być może trzeba będzie zastrzec wyjątki dla pewnych skrajnych przypadków, gdy np. ktoś nagle zaczyna oszukiwać, myśląc, że nie zostanie złapany, by zapobiec niesprawiedliwej śmierci głodowej swojej rodziny. Takie przypadki dają się pogodzić z uczciwością danej osoby, jednakże ten rodzaj oszukiwania nie jest przedmiotem tej pracy.

51 Zob. np. R. Hursthouse, On Virtue Ethics, dz. cyt., s. II. 
(d) Osoba uczciwa, działając zgodnie ze swoim charakterem, nie oszukuje i nie zależy to od tego, czy jej moralne przekonania dotyczące niewłaściwości oszukiwania (gdy jest ono niewłaściwe) są wyraziste.

Innymi słowy, ktoś, kto oszukuje regularnie, gdy stosowne normy moralne zabraniające oszukiwania nie są w jego umyśle wyraziste, ale powstrzymuje się od oszukiwania, gdy są wyraziste, nie osiągnął jeszcze dyspozycji uczciwości. Właśnie coś takiego dotyczy większości z nas, jak sugerują badania Shu oraz wcześniejszy eksperyment Mazar, wykorzystujący Dziesięć przykazań, i pokaźna literatura dotycząca kodeksu honorowego i oszukiwania na uczelniach.

I ostatni wymóg:

(e) Osoba uczciwa, gdy dopuści się oszustwa w sposób wyraźnie niewłaściwy pod względem moralnym, zazwyczaj będzie próbować zapobiec powtórzeniu się oszustwa i będzie przede wszystkim rozczarowana własnym postępowaniem, zamiast uciekać się do samooszukiwania lub racjonalizacji, by nie musieć konfrontować się $z$ własnym oszustwem ${ }^{52}$.

Istnieje mocny empiryczny materiał dowodowy świadczący o tym, że większość z nas nie spełnia również tego wymogu. Wcześniej omówiłem pokrótce, w jaki sposób samooszukiwanie się może oddzielić dopuszczenie się oszustwa od moralnej nagany za takie zachowanie. Wskazałem również, jakimi sposobami ludzie racjonalizują swoje oszukiwanie tak, by nie wydawało się niczym moralnie złym lub przynajmniej ich winą. Zwróćmy również uwagę na przytoczone w tej części dane dotyczące zapamiętania treści kodeksu honorowego przez uczestników eksperymentu. Wydaje się, że gdy dopuścili się oni oszustwa, mieli motywację do zapomnienia tej treści, zmniejszając w ten sposób poczucie dezaprobaty dla własnego postępowania. Jak pisze Shu,

52 Zob. np. tamże. Wymaganie to w odniesieniu do cnót w ogóle zob. J. KupPERMAN, Virtue in Virtue Ethics, „The Journal of Ethics” I3 (2009), s. 245. 
„stwierdziliśmy, że niewłaściwe zachowanie motywuje do łagodności w kwestiach moralnych i prowadzi do stosowania strategii zapominania o moralnych zasadach (...). Ludzie mogą wpaść w spiralę coraz bardziej złagodzonej etyki i jeszcze bardziej nieetycznych zachowań" ${ }^{3}$.

Tak więc łącznie tych warunków uczciwości nie spełnia dziś, jak się zdaje, większość ludzi z badanych populacji i nie jest to wniosek oparty na ankietach, lecz na wynikach badań nad rzeczywistym zachowaniem. Co więcej, nie są to jedyne wymagania, o jakich można tu wspomniećs4. Z moralnego punktu widzenia obraz charakteru, jaki zaczyna się stąd wyłaniać, wygląda raczej ponuro.

Ale nie jest to wniosek, jaki wyciągam $z$ badań naukowych. Przeciwnie, widzę w tej sferze przynajmniej cztery pozytywne aspekty ludzkiego charakteru, które nie pozwalają przypisać ludziom wady nieuczciwości (w odniesieniu do oszukiwania). Oto pierwszy $z$ nich:

(f) Osoba nieuczciwa nie posiada moralnych przekonań, że oszukiwanie jest złe w ogóle oraz w większości poszczególnych przypadków działań powszechnie uważanych za oszustwa. A jeśli akurat posiada takie przekonania, nie przejmuje się nimi i nie odgrywają one znaczącej roli motywacyjnej w jego psychologii.

Czemu na przykład człowiek nieuczciwy miałby uważać oszukanie badaczy na kilka dolarów w badaniu z rozwiązywaniem łamigłówek za coś złego? Gdy jednak moralne przekonania badanych zostały uwyraźnione przez tak prosty zabieg jak

53 L. Shu, F. Gino, M. Bazerman, Dishonest Deed, Clear Conscience..., dz. cyt., s. 344. Zob. téz tamże, s. 332.

54 Są na przykład dowody na to, że nieuczciwe zachowanie jest „zaraźliwe”, gdy jeden z członków grupy w widoczny dla innych sposób postępuje nieuczciwie (F. Gino, S. Ayal, D. Ariely, Contagion and Differentiation in Unethical Behavior..., dz. cyt.; D. DeSteno, P. Valdesolo, Out of Character..., dz. cyt., s. I73-I75). Jednak człowiek uczciwy zazwyczaj nie zacznie zachowywać się bardziej nieuczciwie, widząc, że ktoś inny tak postępuje. 
przypomnienie Dziesięciu przykazań bądź czytanie kodeksu honorowego, większość $z$ nich oszukiwała w mniejszym stopniu lub wcale. Uważam to za zdumiewające świadectwo ich siły moralnej.

A oto kolejny wymóg:

(g) Osoba nieuczciwa, działając zgodnie ze swoim charakterem, nie zobowiąże się z góry i szczerze do uczciwego zachowania się w sytuacji, w której - jak przypuszcza - może oszukać bez żadnego ryzyka wykrycia i uzyskać przez to korzyść finansową bądź jakąkolwiek inną.

Być może twierdzenie to nie jest zawsze prawdziwe. Możliwe, że ktoś nieuczciwy mógłby na wszelkie możliwe sposoby skorzystać z tego, że inni dowiedzieliby się o jego zobowiązaniu. Co do tego zgoda. Ale nie to mam tutaj na myśli - przypuśćmy, że tylko ta osoba nieuczciwa wie o swoim zobowiązaniu. Jaki jest wówczas sens czynienia tego zobowiązania, skoro osoba ta jest nieuczciwa? Ale właśnie tak postąpiła większość uczestników badania Shu - tylko jeden spośród 22 badanych dopuścił się oszustwa, gdy trzeba było podpisać kodeks honorowy.

I znów:

(h) Osoba nieuczciwa, działając zgodnie ze swoim charakterem, będzie próbowała osiągnąć jak największe zyski z oszustwa, gdy uzna, że może się go dopuścić bez żadnego ryzyka wykrycia i z ogólną korzyścią dla siebie.

Okazało się jednak, że przytłaczająca większość uczestników badań tego nie zrobiła. Większość dopuściła się jedynie ograniczonego oszustwa.

Zgodnie $z$ twierdzeniem (h) można utrzymywać, że ci badani byli jednak nieuczciwi, gdyż chcieli zmaksymalizować łącznie zarówno zewnętrzne korzyści, tj. zysk, jak i korzyści wewnętrzne, takie jak zachowanie obrazu samych siebie jako ludzi uczciwych. Ale oto ostatni wymóg nieuczciwości, jaki chcę tu wymienić: 
(i) Osoba nieuczciwa, działając zgodnie ze swoim charakterem (in character), może chcieć, żeby inni uważali ją za uczciwą, ale nie będzie jej mocno zależało na tym, żeby samą siebie uważać za taką.

Dokładnie tego rodzaju twierdzenie wysuwa się w niektórych najnowszych badaniach nad oszukiwaniem przytaczanych w tej pracy.

Nie wiem, jak argumentować na rzecz tego wymagania. Można próbować mu zaprzeczyć, wyobrażając sobie osobę nieuczciwą, która chce postrzegać siebie jako uczciwą. Gdyby taka osoba rzeczywiście chciała być uczciwa, to nie jest oczywiste, czy wciąż zaliczałaby się do osób nieuczciwych. Gdyby jednak wystarczało jej jedynie myśleć o sobie w ten sposób (na przykład na drodze samooszukiwania się), można by postawić zarzut, że wciąż mogłaby być nieuczciwa. Nie wiem, co sądzić o takiej możliwości poza tym, że prowadziłaby ona do wszelkiego rodzaju psychologicznych napięć - nieuczciwe pobudki takiej osoby wciąż pchałyby ją do oszukiwania, a jednocześnie pragnęłaby ona ograniczyć swoje oszustwa, by móc mimo tego uchodzić we własnych oczach za uczciwą. Tego rodzaju psychologiczne napięcia nie są jednak - jak się uważa - udziałem osób niegodziwych lub cnotliwych, które jakoby postępują z pełnym przekonaniem w taki czy inny sposób. Zagadnienie na pewno nie jest wyczerpane, i dlatego nie będę przywiązywał zbyt dużej wagi do wymogu (i).

Warto jeszcze przyjrzeć się możliwości altruistycznego oszukiwania. Jak zasugerowałem na końcu ostatniego punktu, są przypadki oszukiwania, w których motywacja osoby dopuszczającej się oszustwa nie jest bezpośrednio skierowana na nią samą, lecz na innych. Łatwo to zauważyć w przypadku oszustw na uczelni ${ }^{55}$, choć zjawisko nie ogranicza się do tego jednego kontekstu. Gdyby się okazało, że przynajmniej w niektórych tych przypadkach również ostateczna motywacja jest altruistyczna, kłóciłoby się to z przekonaniami na

55 Zob. np. S. Newstead, A. Franklyn-Stokes, P. Armstead, Individual Differences in Student Cheating, dz. cyt. 
temat normalnych dyspozycji osoby nieuczciwej. Szczególnie interesujące pod tym względem mogłyby być przypadki empatycznych oszustw, dokonywanych w imię tego, co dobre dla drugiej osoby, bez względu na to, czy korzysta na tym sam sprawca oszustwa ${ }^{56}$. Niestety, temat jest na tyle mało zbadany, że wkraczanie z nim $\mathrm{w}$ tym momencie na empiryczny grunt byłoby skazane na czcze spekulacje.

\section{Wersja alternatywna - cechy mieszane}

$\mathrm{Na}$ podstawie przytoczonych badań dochodzę do wniosku, że jeśli chodzi o oszukiwanie, większość ludzi nie jest ani uczciwa, ani nieuczciwa. Jest raczej tak, że w tej sferze życia posiadają oni trochę pozytywnych i trochę negatywnych właściwości moralnych. W innym miejscu analizowałem wiele dodatkowych badań dotyczących innych sfer moralności, takich jak pomaganie innym bądź ich krzywdzenie, oraz ich implikacje dla zagadnienia, czy większość ludzi posiada takie cechy jak współczucie czy okrucieństwo ${ }^{57}$. Mój ogólny wniosek jest następujący:

(W) Niewielu ludzi posiada dziś którąkolwiek z tradycyjnych cnót moralnych czy którąkolwiek $z$ tradycyjnych moralnych wad.

Jest to negatywne twierdzenie mówiące o tym, jacy ludzie nie są. Chciałbym jednak zakończyć, przedstawiając w krótkim zarysie pozytywne stanowisko w kwestii charakteru; jest to koncepcja, którą przedstawiłem szczegółowo w swoich dwóch ostatnich książkach. Twierdzę zatem, iż jest również prawdziwe, że:

56 Interesujące wstępne odkrycia można znaleźć w F. Gino, L. Pierce, Dishonesty in the Name of Equity, dz. cyt.

57 Zob. C. Miller, Moral Character..., dz.cyt., Character and Moral Psychology, dz. cyt. 
(I) Większość ludzi faktycznie posiada cechy charakteru związane $z$ różnymi sferami moralności ${ }^{58}$.

Jak to możliwe? Jeśli te cechy nie są tradycyjnymi cnotami ani wadami, to jakie one są? By to zbadać, ponownie posłużę się przykładem oszukiwania. W świetle takich badań jak te, które przywoływałem już w tym artykule, zaczyna wyłaniać się obraz powszechnie żywionych przekonań i pragnień przyczyniających się do oszukiwania. Oto kilka istotnych przykładów ${ }^{59}$ :

- przekonania dotyczące moralnej niesłuszności oszukiwania

- przekonania i pragnienia dotyczące oszukiwania w celu uniknięcia osobistej porażki, zakłopotania itp.

- przekonania i pragnienia dotyczące powstrzymania się od oszukiwania w celu uniknięcia przyłapania, kary itp.

- przekonania i pragnienia dotyczące różnych kosztów (dla siebie i innych) niestosowania się do norm moralnych zabraniających oszukiwania, takich jak potencjalna dezaprobata społeczna, poczucie winy, utrata zaufania itp.

- przekonania dotyczące tego, jak dokonać bilansu tych kosztów i korzyści

- pragnienie dotyczące powstrzymania się od oszukiwania w sytuacji, gdy korzyści z oszustwa nie przeważają (w istotnym stopniu) nad kosztami

- pragnienia dotyczące oszukiwania w sytuacji, gdy korzyści $z$ oszukiwania przeważają (w istotnym stopniu) nad kosztami, przy jednoczesnym pragnieniu - w największym możliwym stopniu - zachowania w oczach swoich $\mathrm{i}$ innych obrazu samego siebie jako osoby uczciwej.

Nie są to oczywiście wszystkie przekonania i pragnienia bezpośrednio dotyczące oszukiwania, jakie większość z nas żywi, ale

58 Jak już wspominałem, należy ograniczyć to twierdzenie do większości ludzi $z$ kręgu kultury Zachodu ostatnich lat. Moja koncepcja charakteru może mieć szersze zastosowanie, ale bym mógł swobodnie postawić taką tezę, musiałbym poczynić dalsze badania.

59 Bardziej szczegółowo opisałem to w C. Miller, Character and Moral Psychology, dz. cyt., $\operatorname{rozd} z$. 3 . 
są one najważniejsze i pomogą mi zilustrować moje pozytywne stanowisko.

Zwróćmy uwagę, że niektóre z tych dyspozycji psychicznych otrzymałyby negatywną ocenę moralną w świetle najbardziej racjonalnych stanowisk etycznych. Spójrzmy dla przykładu na drugi i ostatni zestaw przekonań i pragnień. Inne, takie jak pierwszy, zdają się zasługiwać na bardziej pozytywną ocenę moralną. To dobrze, że większość ludzi zdaje się szczerze wierzyć, iż oszukiwanie (przynajmniej w wielu znanych postaciach) jest złe pod względem moralnym.

Przyjrzyjmy się teraz cesze charakteru, jaką tworzą te i inne powszechne dyspozycje psychiczne bezpośrednio związane z oszukiwaniem ${ }^{60}$. Oto moje kolejne twierdzenie:

(2) Ta cecha charakteru, którą posiada większość dorosłych ludzi, nie odpowiada żadnemu słowu ani pojęciu, jakimi zwykli ludzie oznaczają cechy kojarzone $z$ oszukiwaniem.

Nie jest to cnota uczciwości, ponieważ nie daje się ona zaklasyfikować jako cnota moralna na wielu frontach. Ale nie jest to również wada nieuczciwości, gdyż ona również nie daje się zaklasyfikować jako wada moralna na wielu frontach.

Co to jest więc za cecha? Jeśli nie ma zwykłego terminu na jej określenie, trzeba taki wymyślić. Będę ją zatem nazywał mieszaną cechą oszukiwania (Mixed Cheating Trait); wielkie litery mają zaznaczyć, że jest to ukuty przeze mnie termin techniczny. Słowo „mieszana” odnosi się wyłącznie do moralnej oceny tej cechy, jako że ma ona zarówno pozytywne, jak i negatywne aspekty moralne. "Oszukiwanie” wskazuje na dziedzinę moralności, której ta cecha dotyczy ${ }^{6}$. Dlaczego nigdy nie wymyślono dla niej terminu i - jak

60 Związek pomiędzy dyspozycjami psychicznymi a cechami charakteru zob. tamże, rozdz. I.

${ }_{61}$ A co z elementem "cecha” mieszanych cech agresji (Mixed Aggression Traits)? W Moral Character..., dz. cyt., rozdz. I i Character and Moral Psychology, dz. cyt., rozdz. I szeroko omówiłem właściwy - moim zdaniem - sposób podejścia do metafizyki cech charakteru. W szczególności, moja prowizoryczna propozycja zakłada, że każdą grupę wzajemnie powiązanych dyspozycji psychicznych 
się zdaje - przeoczano ją przez tysiące lat historii ludzkości, to ciekawa kwestia; próbowałem ją pokrótce wyjaśnić w innej pracy ${ }^{62}$. Moje stanowisko odnośnie do tej dziedziny moralności można streścić następująco:

(3) Większość ludzi jako część swojego charakteru posiada mieszaną cechę oszukiwania, a nie cnotę uczciwości bądź wadę nieuczciwości.

Opuszczając konkretną dziedzinę moralności, którą jest oszukiwanie, można ogólnie ująć moje stanowisko w sposób następujący:

(4) Większość ludzi jako część charakteru posiada cechy mieszane, a nie różnego rodzaju cnoty bądź wady.

Można to w inny sposób zaprezentować na wykresie. Na rys. I widzimy kontinuum rozciągające się od pełnej cnoty do pełnej wady, zaś cechy mieszane znajdują się pośrodku, nie będąc ani cnotą, ani wadą.

dotyczących sfery moralności należy zaliczać do cech charakteru. Wobec tego zatem, co powied ziano wyżej, przekonania i pragnienia dotyczące wyrządzenia krzywdy oprawcy w celu zemsty należałoby uznać za konstytutywne elementy rzeczywistej cechy charakteru. Szerszą dyskusję zob. w dwóch rozdziałach przywołanych na początku tego przypisu. Dziękuję Iskrze Filevy za zachętę do rozwinięcia tematu.

62 Zob. C. Miller, Character and Moral Psychology, dz. cyt., rozdz. 7. Ważne, by właściwie rozumieć sens, w jakim cecha ta nazywana jest "mieszaną”. Nie twierdzę, że mieszana cecha oszukiwania jest w pewnych sytuacjach bądź kontekstach cnotą, a w innych wadą. Twierdzę raczej, że ta cecha nie jest cnotą w żadnej sytuacji ani kontekście; nie jest też wadą ani czymś całkowicie dobrym bądź złym pod względem moralnym w żadnej sytuacji ani kontekście. Jest raczej tak, że w każdej poszczególnej sytuacji lub kontekście, w jakich ktoś tę cechę posiada, nie jest ona ani cnotą, ani wadą; ani niczym całkowicie dobrym, ani niczym całkowicie złym. 
- CHRISTIAN B. MILLER .

Rys. I. Kontinuum rozciągające się

od pełnej cnoty do pełnej wady

\begin{tabular}{c|c|c} 
Duże Średnie Słabe & Bliżej cnoty Bliżej wady & Słabe Średnie Duże \\
\hline Cnota uczciwości & Ani cnota, ani wada & Wada nieuczciwości
\end{tabular}

Próg uczciwości

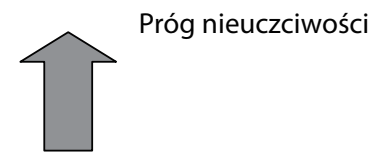

Większość ludzi

Zgadza się to również z faktem, że:

(5) Niewielu ludzi posiada w pewnym stopniu jedną bądź więcej cnót, lecz raczej odpowiednią cechę (bądź cechy) mieszaną,

oraz $z$ faktem, że:

(6) Niewielu ludzi posiada w pewnym stopniu jedną bądź więcej wad, lecz raczej odpowiednią cechę (bądź cechy) mieszaną,

a nawet $z$ faktem, że:

(7) Pewni ludzie nie posiadają cech mieszanych, cnót ani wad jako czynników wywołujących ich zachowanie istotne pod względem moralnym.

Do takich ludzi mogą zaliczać się dzieci, psychopaci i osoby $z$ ciężkimi upośledzeniami umysłowymi, które nie tylko blokują uaktywnienie się tych cech charakteru, lecz także faktycznie uniemożliwiają ich nabycie.

Chciałbym teraz zwrócić szczególną uwagę na dwa dodatkowe aspekty cech mieszanych - behawioralny i motywacyjny. Wiemy, że cnota moralna powinna w powtarzalny sposób objawiać się w cnotliwym zachowaniu tego, kto ją posiada, w odpowied- 
nich okolicznościach, o ile inne czynniki pozostają bez zmian. Wiemy również, że wada moralna w powtarzalny sposób objawia się w niegodziwym zachowaniu. Natomiast cecha mieszana powinna w powtarzalny sposób objawiać się w... no właśnie - w czym?

Jeśli zgodnie z rys. I określona cecha mieszana znajduje się pośrodku pomiędzy cnotą i wadą, to powinniśmy oczekiwać, że ten, kto ją posiada, będzie przejawiał na przestrzeni czasu różnorodne, zarówno pozytywne, jak i negatywne moralnie zachowania. Taki wzorzec rzeczywistego zachowania może nawet wydać się niezależnym obserwatorom pofragmentowany. Weźmy raz jeszcze pod uwagę oszukiwanie i przypomnijmy sobie listę różnych, powszechnie żywionych - jak twierdziłem - przekonań i pragnień. Mając w pamięci taki zbiór, nie będziemy zaskoczeni, że ludzie, którzy je posiadają, zachowują się rozmaicie pod względem moralnym. W pewnych przypadkach, w których nadarza się łatwa okazja do oszukania, osoba posiadająca cechę mieszaną nie oszuka. Jednak w innych, nawet nieznacznie odmiennych sytuacjach, często dopuszczać się będzie oszustwa. Na przykład ta sama osoba może ściągać na egzaminie, gdy wie, że nikt jej nie przyłapie, ale na innych zajęciach, gdy nadarzy się okazja do bezkarnego oszustwa, powstrzyma się od niego po podpisaniu kodeksu honorowego. W języku psychologii osoba taka wykazuje wysoki stopień wewnątrzosobowej zmienności zachowania związanego $z$ oszukiwaniem. Zgodnie $z$ moim schematem:

(8) Osoba posiadająca mieszaną cechę oszukiwania będzie niekiedy, bez odpowiedniego moralnego uzasadnienia, oszukiwać w pewnych sytuacjach, w których nadarzy się po temu okazja, nawet gdy nie będzie do tego zmuszona, a odpowiednie zasady będą właściwe i sprawiedliwe.

Ale jest również prawdą, że:

(9) Osoba posiadająca mieszaną cechę oszukiwania będzie niekiedy powstrzymywać się od oszustwa w sytuacjach, któ- 
rych będzie wolnym i dobrowolnym uczestnikiem i w których odpowiednie zasady będą właściwe i sprawiedliwe, nawet jeśli oszustwo zapewni jej uzyskanie określonych korzyści dla siebie i będzie wiedzieć, że nie zostanie przyłapana.

Można to zilustrować na wykresie, posługując się przykładem Larry'ego i jego zachowania w czterech różnych sytuacjach ${ }^{63}$.

Rys. 2. Profil oszukiwania Larry'ego

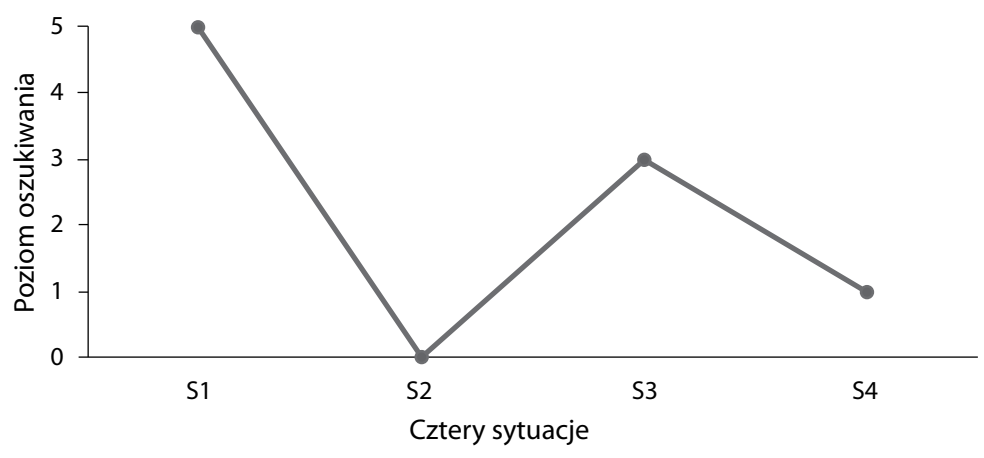

W tym przykładzie oszukiwanie Larrýego jest różne w czterech różnych sytuacjach. SI może być na przykład wypełnianiem formularza podatkowego, kiedy to Larry zawsze oszukuje w znacznym stopniu, podczas gdy $\mathrm{S}_{2}$ może być rozwiązywaniem zadań na egzaminie domowym, przy okazji którego Larry podpisał kodeks honorowy i nigdy nie robi niczego złego.

Tę samą koncepcję można zaprezentować jeszcze w inny sposób:

63 W zilustrowaniu tych twierdzeń może pomóc narzędzie powszechnie wykorzystywane w psychologii profili. Profil to zbiór punktów przyznawanych tym samym rodzajom zachowania prezentowanych przez daną osobę w różnych sytuacjach. Pomoc w tej materii znalazłem w omówieniu profili w artykule Michaela R. Furra [Profile Analysis in Person-Situation Integration, ,Journal of Research in Personality” 43 (2009), s. 196-207]. Ściślej mówiąc, Furr zwraca uwagę, że powyższa charakterystyka stosuje się wyłącznie do jednego spośród wielu rodzajów profili, jakie wykorzystuje się w psychologii (tamże, s. 197). 
Rys. 3. Częstotliwość oszukiwania Larry'ego

na różnym poziomie na przestrzeni roku

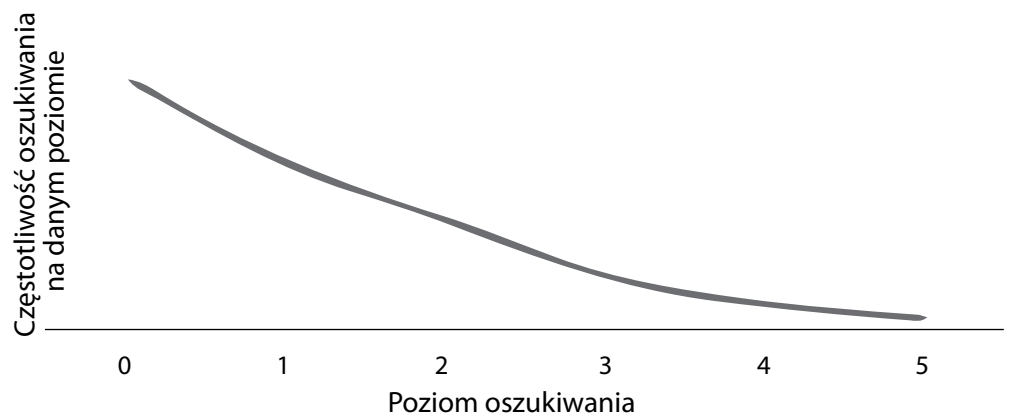

Widzimy tutaj zachowanie Larry'ego na przestrzeni całego roku w wielu różnych sytuacjach sprzyjających oszukaniu. Zwróćmy uwagę - co być może nie jest zaskoczeniem - że przez większość czasu nie dopuszcza się on znacznych oszustw. W końcu większość z nas często unika oszukiwania, zwłaszcza gdy widzą nas inni, i istnieją oczywiste egoistyczne powody takiego stanu rzeczy. Mimo to widzimy, że na przestrzeni roku zachowanie Larry'ego naznaczone jest różnorodnymi odcieniami oszustwa. Jest wiele sytuacji, w których oszukuje on w stopniu umiarkowanym (na przykład zawyżając o 50 dolarów wydatki na cele charytatywne w formularzu podatkowym), i kilka, w których oszukuje w bardzo dużym stopniu (na przykład znajdując w Internecie odpowiedzi na pytania $z$ egzaminu domowego). Biorąc zatem pod uwagę tę wewnątrzosobową zmienność, okazuje się, że to, jak bardzo Larry oszukuje w określonej sytuacji, nie pozwala przewidzieć, jak bardzo oszuka w dowolnej innej sytuacji 64 .

To samo, co dotyczy oszukiwania i mieszanych cech oszukiwania, zachowuje również ważność - być może w różnym stopniu - w przypadku pozostałych dziedzin moralności i odpowiadających im cech mieszanych. Innymi słowy:

64 Podobne twierdzenie dotyczące zachowania niezwiązanego z moralnością zob. W. Fleeson, Toward a Structure- and Process-Integrated View of Personality: Traits as Density Distributions of States, "Journal of Personality and Social Psychology" 80 (200I), s. IOII-I027. 
(Io) Osoba posiadająca pewną cechę mieszaną będzie zwykle, w różnych sytuacjach odpowiadających tej cesze, wykazywać zachowania, które zewnętrznym obserwatorom mogą wydawać się pofragmentowane.

Twierdzenie to dotyczy jawnego zachowania. Ale co powiedzieć o cechach mieszanych i motywach leżących u podstaw danego zachowania?

Cechy mieszane, jak wszystkie cechy charakteru, wpływają na zachowanie, będąc pierwszym czynnikiem wywołującym przekonania, pragnienia, emocje itp. Te stany umysłu są z kolei przyczynami dającymi początek działaniu. Jak więc - z normatywnego punktu widzenia - wygląda wzorzec przekonań, pragnień itp. pojawiających się w umyśle pod wpływem cech mieszanych? Moja odpowiedź na to pytanie jest niemal taka sama jak w przypadku działań. Jako cechy pośrednie pomiędzy moralnymi cnotami a wadami cechy mieszane będą wywoływać zmienne wzorce motywacji - w niektórych przypadkach motywy takie będą godne podziwu (jak na przykład pomaganie innym wypływające $z$ empatii), a w innych godne potępienia (jak na przykład pomaganie innym w celu podtrzymania dobrego nastroju). Moralną jakość motywacji będzie cechować wysoki stopień wewnątrzosobowej zmienności, podobnie jak było to w przypadku zachowania.

Ponadto, podobnie jak w przypadku wszystkich cech moralnych, istnieją pewne psychologiczne czynniki powiązane z cechami mieszanymi, które zwiększają motywację do podjęcia pewnych działań, oraz czynniki psychologiczne, które zwiększają motywację do niepodejmowania pewnych działań. Oba te punkty rozpatrzę teraz w kontekście psychologii oszukiwania.

Jeśli weźmiemy pod uwagę różne wymienione wcześniej przekonania i pragnienia, nie będzie zaskoczeniem, że w przypadku mieszanej cechy oszukiwania specyficzne psychologiczne zmienne, które mogą uaktywnić tę cechę i wzmóc oszukiwanie, to m.in.:

- oczekiwane uniknięcie wykrycia

- oczekiwane uniknięcie kary

- oczekiwana okazja do uniknięcia zakłopotania

+ oczekiwana okazja do uniknięcia porażki. 
Zwróćmy uwagę, że powyższe zmienne nie są czymś, co można by uznać za cnotliwe czynniki wzmagające oszukiwanie - spodziewamy się, że oszukiwanie osoby uczciwej nie będzie w znaczący sposób zależeć od tego, czy oszustwo pozwoli jej uniknąć zakłopotania.

Robiąc krok do tyłu, możemy ogólniej powiedzieć, że:

(II) Istnieją określone czynniki wzmagające mieszaną cechę oszukiwania danej osoby, które mogą wpłynąć na nią w taki sposób, że wzrasta motywacja do oszukania, gdy nadarza się okazja do oszustwa, w porównaniu z motywacją bez działania owego czynnika ${ }^{65}$.

Choć jest to bez wątpienia nadmierne uproszczenie, rolę czynnika wzmagającego, takiego jak uniknięcie zakłopotania, można zilustrować na następującym wykresie:

Rys. 4. Profil oszukiwania Larry'ego

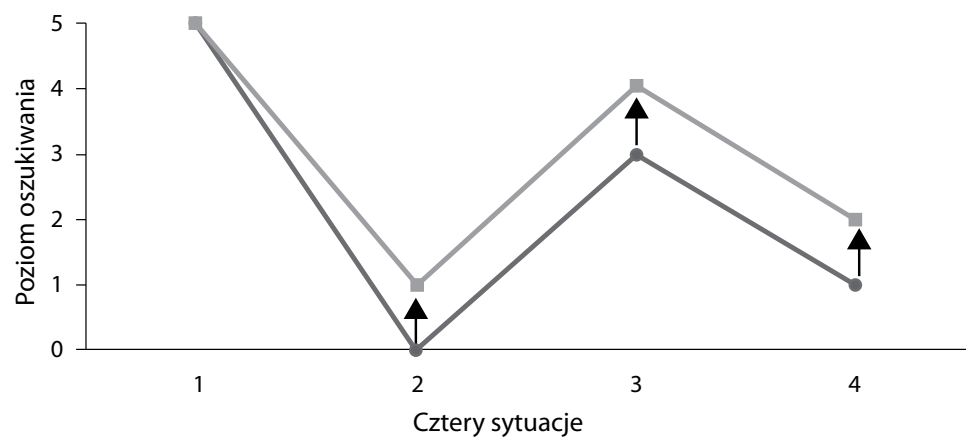

Oczywiście uproszczeniem jest przypuszczać, że oszukiwanie Larry'ego zwiększy się w tym samym stopniu w tych czterech sytuacjach, ale wykres ma jedynie pomóc zilustrować moją myśl.

65 Zwróćmy uwagę, że związana z tymi czynnikami aktywność psychologiczna nie musi być podejmowana w sposób świadomy - często jest ona w dużej mierze automatyczna lub przebiega podświadomie. 
Jak istnieją czynniki wzmagające oszukiwanie, tak i:

(I2) Istnieją określone czynniki hamujące mieszaną cechę oszukiwania, które mogą wpłynąć na nią w taki sposób, że wzrasta motywacja do nieoszukania, gdy nadarza się okazja do oszustwa, w porównaniu z motywacją bez działania owego czynnika.

Oto przykłady takich czynników:

- oczekiwane niepowodzenie w oszukaniu

+ oczekiwane poczucie winy

- psychologicznie wyraziste normy moralne zakazujące oszukiwania.

Czynniki te są w dużej mierze intuicyjne i literatura psychologiczna potwierdza, że faktycznie funkcjonują one jako czynniki hamujące ${ }^{66}$. I znów, niektóre $z$ tych zmiennych nie są związane $z$ cnotą uczciwości (tak jak oczekiwane poczucie winy), a inne mogą być (takie jak wyraziste normy moralne).

W ramach podsumowania podaję bardziej ogólne twierdzenie dotyczące motywacji i cech mieszanych:

(13) W przypadku każdej cechy mieszanej możemy oczekiwać, że moralna jakość wywoływanych przez nią motywów będzie odznaczać się wysokim stopniem wewnątrzosobowej zmienności. Istnieją ponadto określone czynniki wzmagające i hamujące, które mogą wpłynąć na motywację do działania w sposób odpowiadający tej cesze. Jakie to będą czynniki wzmagające i hamujące dla danej cechy mieszanej, jest wypadkową dyspozycji psychicznych tworzących tę cechę.

Jeśli moje podejście jest właściwe, to oczywiście nie da się przedstawić żadnej prostej koncepcji motywacji.

W tym miejscu można wyszczególnić inne właściwości cech mieszanych: są na określone sposoby stałe i niezmienne w zależności

66 Więcej na temat czynników wzmagających i hamujących zob. C. Miller, Moral Character..., dz.cyt., rozdz. 7 i 8. 
od sytuacji; mogą się różnić u różnych osób; różnią się stopniem konkretności bądź ogólności, w jakim mogą być zindywidualizowane; procesy psychiczne przez nie wywoływane często dokonują się nieświadomie itp. Nie będę tu jednak wdawał się w szczegóły. Mam nadzieję, że mój artykuł wzbudzi zainteresowanie tym nowym podejściem do rozumienia charakteru ${ }^{67}$.

Przełożył Patryk Krajewski

\section{Bibliografia}

Adams R., Motive Utilitarianism, „The Journal of Philosophy” 73 (I976), S. $467-48 \mathrm{I}$.

Adams R., A Theory of Virtue: Excellence in Being for the Good, Oxford: Oxford University Press, 2006.

Anderman E., Murdock T. (eds.), Psychology of Academic Cheating, Amsterdam: Elsevier Academic Press, 2007.

Bandura A. i in., Mechanisms of Moral Disengagement in the Exercise of Moral Agency, "Journal of Personality and Social Psychology" 7I (I996), s. 364-374.

Baxley A., Kant's Theory of Virtue: The Value of Autocracy, Cambridge: Cambridge University Press, 20Io.

Blasi A., Bridging Moral Cognition and Moral Action: A Critical Review of the Literature, "Psychological Bulletin” 88 (I980), s. I-45.

Bloodgood J., Turnley W., Mudrack P., The Influence of Ethics Instruction, Religiosity, and Intelligence on Cheating Behavior, "Journal of Business Ethics" 82 (2008), s. 557-57I.

DeSteno D., Valdesolo P., Out of Character: Surprising Truths about the Liar, Cheat, Sinner (and Saint) Lurking in All of Us, New York: Crown Publishing Group, 20II.

67 Tamże. Jestem niezmiernie wdzięczny Nataszy Szutcie za zaproszenie mnie na konferencję poświęconą sytuacjonizmowi, której efektem jest ten artykuł. Materiał w nim zaprezentowany opiera się głównie na mojej książce Character and Moral Psychology, rozdz. 2 i 3. Prace nad nim zostały częściowo sfinansowane $z$ grantu przyznanego przez Fundację Johna Templetona i fundację Templeton World Charity. Poglądy zaprezentowane w tym artykule są moje i nie muszą odzwierciedlać poglądów ww. fundacji. 
Diener E., Wallbom M., Effects of Self-Awareness on Antinormative Behavior, "Journal of Research in Personality" Io (I976), s. I07-III.

Dienstbier R., Munter P., Cheating as a Function of the Labeling of Natural Arousal, "Journal of Personality and Social Psychology" I7 (I97I), s. 208-2I3.

Faulkender P. i in., The Case of the Stolen Psychology Test: An Analysis of an Actual Cheating Incident, „Ethics \& Behavior” 4 (1994), s. 209-2I7.

Flanagan O., Varieties of Moral Personality, Cambridge, MA: Harvard University Press, I99I.

Fleeson W., Toward a Structure- and Process-Integrated View of Personality: Traits as Density Distributions of States, „Journal of Personality and Social Psychology" 80 (200I), s. IOI I-I027.

Furr M.R., Profile Analysis in Person-Situation Integration, "Journal of Research in Personality" 43 (2009), s. I96-207.

Gillath O. i in., Attachment, Authenticity, and Honesty: Dispositional and Experimentally Induced Security Can Reduce Self-and Other-Deception, "Journal of Personality and Social Psychology" 98 (2010), s. 84I-855.

Gino F., Ayal S., Ariely D., Contagion and Differentiation in Unethical Behavior: The Effect of One Bad Apple on the Barrel, „Psychological Science" 20 (2009), s. 393-398.

Gino F. i in., Unable to Resist Temptation: How Self-Control Depletion Promotes Unethical Behavior, „Organizational Behavior and Human Decision Processes" II5 (201I), s. I9I-203.

Gino F., Margolis J., Bringing Ethics into Focus: How Regulatory Focus and Risk Preferences Influence (Un)etbical Behavior, „Organizational Behavior and Human Decision Processes" II5 (2011), s. I45-156.

Gino F., Pierce L., Dishonesty in the Name of Equity, „Psychological Science" 20 (2009), S. II53-II60.

Gordon A., Miller A., Perspective Differences in the Construal of Lies: Is Deception in the Eye of the Beholder?, "Personality and Social Psychology Bulletin" 26 (2000), s. 46-55.

Haines V. i in., College Cheating: Immaturity, Lack of Commitment, and the Neutralizing Attitude, "Research in Higher Education” 25 (I986), s. 342-354.

Houston J., Curvilinear Relationships among Anticipated Success, Cheating Behavior, Temptation to Cheat, and Perceived Instrumentality to Cheat, "Journal of Educational Psychology" 70 (1978), s. 758-762. 
Hursthouse R., On Virtue Ethics, Oxford: Oxford University Press, I999.

Krein H. i in., Cheating during the College Years: How Do Business Students Compare?, "Journal of Business Ethics" 72 (2007), s. 197-206.

Kupperman J., Virtue in Virtue Ethics, "The Journal of Ethics” I3 (2009), S. 243-255.

Mazar N., Amir O., Ariely D., The Dishonesty of Honest People: A Theory of Self-Concept Maintenance, "Journal of Marketing Research" 45 (2008), s. 633-644.

Mazar N., Amir O., Ariely D., More Ways to Cheat: Expanding the Scope of Dishonesty, "Journal of Marketing Research" 45 (2008), s. 650-653.

McCabe D., Butterfield K., Treviño L., Academic Dishonesty in Graduate Business Programs: Prevalence, Causes, and Proposed Action, "Academy of Management Learning and Education" 5 (2006), s. 294-305.

McCabe D., Treviño L., Academic Dishonesty: Honor Codes and Other Contextual Influences, "Journal of Higher Education" 64 (1993), s. $522-538$.

McCabe D., Treviño L., Individual and Contextual Influences on Academic Dishonesty: A Multicampus Investigation, „Research in Higher Education" 38 (1997), s. 379-396.

McCabe D., Treviño L., Butterfield K., Cheating in Academic Institutions: A Decade of Research, „Ethics \& Behavior” II (200I), s. 219-232.

Mead N. i in., Too Tired to Tell the Truth: Self-Control Resource Depletion and Dishonesty, "Journal of Experimental Social Psychology" 45 (2009), s. 594-597.

Miller C., Moral Character: An Empirical Theory, Oxford: Oxford University Press, 2013.

Miller C., Character and Moral Psychology, Oxford: Oxford University Press, 2014.

Murdock T., Stephens J., Is Cheating Wrong? Students' Reasoning about Academic Dishonesty [w:] E. Anderman, T. Murdock (eds.), Psychology of Academic Cheating, Amsterdam: Elsevier Academic Press, 2007, s. 229-25I.

Nagin D., Pogarsky G., An Experimental Investigation of Deterrence: Cheating, Self-Serving Bias, and Impulsivity, "Criminology" 4I (2003), s. I67-194. 
Newstead S., Franklyn-Stokes A., Armstead P., Individual Differences in Student Cheating, "Journal of Educational Psychology" 88 (1996), s. 229-24I.

Ogilby S.M., The Ethics of Academic Behavior: Will it Affect Professional Behavior?, "Journal of Education for Business" 7I (I995), s. 92-96.

O'Rourke J. i in., Imitation is the Sincerest Form of Cheating: The Influence of Direct Knowledge and Attitudes on Academic Dishonesty, „Ethics \& Behavior” 20 (2010), s. 47-64.

Rick S., Loewenstein G., Commentaries and Rejoinder to 'The Dishonesty of Honest People', "Journal of Marketing Research” 45 (2008), s. $645-653$.

Rokovski C., Levy E., Academic Dishonesty: Perceptions of Business Students, "College Student Journal” 4I (2007), s. 466-48I.

Samuels S., Casebeer W., A Social Psychological View of Morality: Why Knowledge of Situational Influences on Behaviour Can Improve Character Development Practices, "Journal of Moral Education" 34 (2005), s. 73-87.

Shu L., Gino F., Bazerman M., Dishonest Deed, Clear Conscience: When Cheating Leads to Moral Disengagement and Motivated Forgetting, „Personality and Social Psychology Bulletin” 37 (201I), s. 330-349.

Simkin M., McLeod S., Why Do College Students Cheat?, "Journal of Business Ethics" 94 (20I0), s. 44I-453.

Singhal A., Factors in Students' Dishonesty, „Psychological Reports” 5I (1982), s. 775-780.

Smith C., Ryan E., Diggins D., Moral Decision Making: Cheating on Examinations, "Journal of Personality" 40 (I972), s. 640-660.

Sykes G., Matza D., Techniques of Neutralization: A Theory of Delinquency, „American Sociological Review” 22 (I957), s. 664-670.

Taradi S. i in., Students come to Medical Schools Prepared to Cheat: A Multi-Campus Investigation, "Journal of Medical Ethics" 36 (2010), s. $666-670$.

Thorkildsen T., Golant C., Richesin L., Reaping What We Sow: Cheating as a Mechanism of Moral Engagement [w:] E. Anderman, T. Murdock (eds.), Psychology of Academic Cheating, Amsterdam: Elsevier Academic Press, 2007, s. I7I-202.

'Tibbetts S., Gender Differences in Students' Rational Decisions to Cheat, „Deviant Behavior” I8 (1997), s. 393-4I4. 
Vohs K., Schooler J., The Value of Believing in Free Will: Encouraging a Belief in Determinism Increases Cheating, „Psychological Science” I9 (2008), s. 49-54.

Williams K., Nathanson C., Paulhus D., Identifying and Profiling Scholastic Cheaters: Their Personality, Cognitive Ability, and Motivation, "Journal of Experimental Psychology: Applied” I6 (2010), s. 293-307.

Zhong C., Bohns V., Gino F., Good Lamps are the Best Police: Darkness Increases Dishonesty and Self-Interested Behavior, „Psychological Science" 2I (20I0), s. 3II-3I4.

Key words Abstract

character, In this paper I focus on just one area of our moral lives,

honesty, namely cheating motivation and behavior, and examine dishonesty, whether there is any empirical support for the relevant cheating, virtue of honesty or vice of dishonesty. In the process, virtue, vice I also outline several requirements for being honest and dishonest. I eventually show why, in light of the current psychological evidence, these requirements do not seem to be met. Hence my view is that most people are neither honest nor dishonest. I end by stepping back and presenting some of the details of my Mixed Trait approach to thinking about the character traits which, I claim, most people actually do possess.

Christian B. Miller jest profesorem filozofii na Uniwersytecie Wake Forest. Główny przedmiot jego zainteresowań stanowią: etyka normatywna, metaetyka, psychologia moralna oraz filozofia religii. Jest autorem 53 artykułów, redaktorem trzech antologii, jak również autorem dwóch książek: Moral Character: An Empirical Theory (Oxford University Press); Character and Moral Psychology (Oxford University Press). Jest także dyrektorem tzw. Character Project. Strona internetowa: www.wfu.edu/ millerc. Adres e-mail: millerc@wfu.edu. 